\title{
A General and Direct Reductive Amination of Aldehydes and Ketones with Electron-Deficient Anilines
}

\author{
Jakob Pletz \\ Bernhard Berg \\ Rolf Breinbauer* \\ Institute of Organic Chemistry, Graz University of Technology, \\ Stremayrgasse 9, 8010 Graz, Austria \\ breinbauer@tugraz.at \\ In memoriam Philipp Köck
}

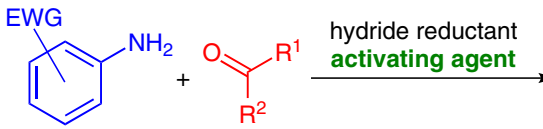

3 methods
A) $\mathrm{BH}_{3} \cdot \mathrm{THF}, \mathrm{AcOH}, \mathrm{CH}_{2} \mathrm{Cl}_{2}, 0-20^{\circ} \mathrm{C}$
B) $\mathrm{BH}_{3} \cdot \mathrm{THF}, \mathrm{TMSCl}, \mathrm{DMF}, 0^{\circ} \mathrm{C}$
C) $\mathrm{NaBH}_{4}, \mathrm{TMSCl}, \mathrm{DMF}, 0^{\circ} \mathrm{C}$

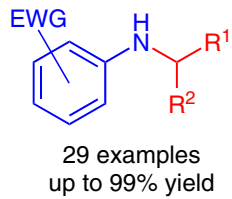

up to $99 \%$ yield

12 anilines

14 ketones

3 aldehydes
Received: 01.12.2015

Accepted after revision: 20.01.2016

Published online: 01.03.2016

DOI: 10.1055/s-0035-1561384; Art ID: ss-2015-t0688-fa

License terms: (C)

Abstract In our ongoing efforts in preparing tool compounds for investigating and controlling the biosynthesis of phenazines, we recognized the limitations of existing protocols for $\mathrm{C}-\mathrm{N}$ bond formation of electron-deficient anilines when using reductive amination. After extensive optimization, we have established three robust and scalable protocols for the reductive amination of ketones with electron-deficient anilines, by using either $\mathrm{BH}_{3} \cdot \mathrm{THF} / \mathrm{AcOH} / \mathrm{CH}_{2} \mathrm{Cl}_{2}$ (method $\mathrm{A}$ ), with reaction times of several hours, or the more powerful combinations $\mathrm{BH}_{3} \cdot \mathrm{THF} / \mathrm{TMSCl} / \mathrm{DMF}$ (method B) and $\mathrm{NaBH}_{4} / \mathrm{TMSCl} / \mathrm{DMF}$ (method C), which give full conversions for most substrates within 10 to 25 minutes. The scope and limitations of these reactions have been defined for 12 anilines and 14 ketones.

Key words amines, anilines, borane, hydride, reductive amination, ketones, process chemistry, sodium borohydride

\section{Introduction}

In 2005 I saw at a conference in London a poster by the structural biologist and enzymologist Wulf Blankenfeldt, who presented his progress on the investigation of the biosynthesis of phenazines, a class of bacterial natural products among which the virulence factor pyocyanine is probably its most prominent member. ${ }^{1}$ He had already solved the structure of several enzymes along this biosynthetic pathway, but there were several open mechanistic questions, for which it would be important to have substrate analogues binding to these proteins. These probes would ideally serve also as inhibitors of these enzymes, potentially allowing the chemical control of the biosynthesis pathway - an attractive goal and formidable challenge for a synthetic organic chemist and the starting point of a fruitful collaboration between our two groups.

Our first goal was the design and synthesis of analogues of intermediates in the transformation catalyzed by the protein PhzA/B. According to Wulf's proposal, ${ }^{1}$ this enzyme was expected to catalyze the imine formation between the putative aminoketone $\mathbf{B}$, resulting from the transformation of PhzF with dihydrohydroxyanthranilic acid (DHHA; A), with itself, thereby establishing the tricyclic skeleton $\mathbf{C}$, from which after a series of oxidation reactions phenazinecarboxylic acid $\mathbf{E}$ will be formed (Scheme 1). In my group the project was pursued by two talented students: Almut Graebsch synthesized in her diploma thesis the first ligands, which could be shown, by isothermal calorimetry<smiles>N[C@H]1C(C(=O)O)=CC=CC1O</smiles>

DHHA

(

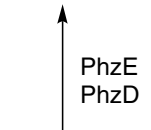

chorismic acid<smiles>O=C(O)c1ccc2nc3c(C(=O)O)cccc3nc2c1</smiles>

Scheme 1 Biosynthesis of phenazines 
(ITC) and X-ray crystallography of the protein ligand complex, to bind to PhzA/B. This work was continued by Matthias Mentel, who, after the move of our laboratory to the University of Leipzig, used information gained from X-ray crystallography and ITC to design even more potent molecules, ultimately leading to two important ligands, which we named 'Phenazistatin' (F) and 'Maverick' (G) (Figure 1). Phenazistatin, which binds to PhzA/B with a $K_{d}=51 \mathrm{nM}$, is a strongly affine ligand, mimicking the intermediate after the first imine formation catalyzed by PhzA/B. The X-ray crystal structure of the protein-ligand complex of PhzA/B.F proved important for the unambiguous assignment of the biological purpose and mechanistic details of PhzA/B function. ${ }^{2}$ Compound $\mathbf{G}$ was isolated in $1 \%$ yield, as Matthias noticed it as a minor byproduct in the Ullmann-Goldberg reaction of 2-bromobenzoic acid with 3-aminopiperidine, where waste products of the Ullmann-Goldberg reaction led to racemic $\mathbf{G}$ by bromination of the main product. When subjecting it to ITC and X-ray crystal structure analysis, we made the completely unexpected and stunning observation that for racemic $\mathbf{G}$ both enantiomers were found in the binding pocket of PhzA/B simultaneously. We have carefully investigated this case, which is the first example in which the textbook notion of eutomer vs. distomer behavior of racemic drugs is not valid, since each enantiomer of Maverick (G) binds more strongly to the protein than its racemate. ${ }^{3}$

After the move of our laboratory to Graz, Jakob Pletz continued the work of Matthias Mentel, and tried to prepare even more affine ligands of PhzA/B and analogues of Maverick, exploring if other molecules would also exhibit the amazing phenotype of simultaneous binding of racemic

\section{Biographical sketches}
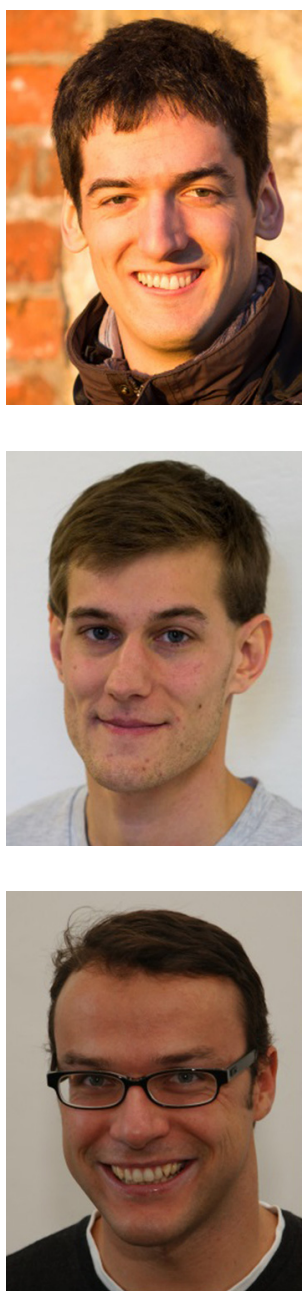

Jakob Pletz was born in Oberpullendorf (Austria) in 1987. He obtained his B.Sc. in chemistry and his M.Sc. in technical chemistry from the Graz University of Technology and the University of Graz. After an Erasmus exchange stay in the laboratory of

Bernhard Berg was born in San Francisco (USA) in 1990. He finished his primary education (elementary and high school) in Linz (Austria) and began studying chemistry at the Graz University of Technology in 2011,
Professor John K. Gallos at the Aristotle University of Thessaloniki (Greece), he carried out his Diploma thesis project under the guidance of Professor Rolf Breinbauer. Since 2012 he has been working on his Ph.D. thesis on the synthesis and bio- logical characterization of analogues of amine-containing natural products under the guidance of Professor Rolf Breinbauer at the Graz University of Technology (Austria). accomplishing his B.Sc. thesis under the supervision of Prof. Rolf Breinbauer in early 2015. In the summer 2015 he worked in the laboratory of Nancy I. Totah, in the Department of Chemistry at Syracuse University (USA).
Since 2015 he has been pursuing his Master studies in technical chemistry at the Graz University of Technology (Austria).
Rolf Breinbauer was born in Schärding (Austria) in 1970. He studied chemistry at the Vienna University of Technology and the University of Heidelberg, carrying out his Diploma thesis project under the guidance of Professor Günter Helmchen. From 1995 to 1998, he worked as a Ph.D. student under the guidance of Professor Manfred T. Reetz at the Max-Planck-Institut für Kohlenforschung in Mül-
heim/Ruhr (Germany). After working as a postdoctoral researcher with an ErwinSchrödinger fellowship in the laboratory of Professor Eric N. Jacobsen (Harvard University, USA), he moved in 2000 to Dortmund (Germany) as a group leader at the Max-Planck Institute of Molecular Physiology (department head: Professor Herbert Waldmann) and as a junior professor at the University of Dortmund. From 2005 to 2007 he was a professor of organic chemistry at the University of Leipzig. Since 2007, he has been a full professor of organic chemistry at the Graz University of Technology in Graz (Austria). His research interests encompass the design and synthesis of tool compounds for chemical biology and the development of new synthetic methods. 
<smiles>O=C(O)c1cc(Br)ccc1N[C@@H]1CCCC(C(=O)O)C1</smiles>

Phenazistatin<smiles>O=C(O)c1cc(Br)ccc1N[C@H]1CCCNC1</smiles>

Maverick
Figure 1 Structures of Phenazistatin (F) and Maverick (G)

molecules in a single binding pocket. Jakob soon recognized that a major limitation in his work was the inefficiency of the Ullmann-Goldberg reaction for the $\mathrm{C}-\mathrm{N}$ bond formation. ${ }^{4}$ Despite considerable efforts and some success in improving the yields for some substrates by optimizing the reaction conditions, no reliable protocol could be found which was suitable for the diverse and highly functionalized substrates of our ligands. Jakob suggested a different route in which the $\mathrm{C}-\mathrm{N}$ bond is formed with the alkyl carbon by using reductive amination as the strategic transformation, which should lead to higher yields and have the additional advantage that the required ketone substrates are more available than the alicyclic amines necessary for the Ullmann-Goldberg route (Figure 2). The lack of control of the resulting stereogenic center should not bother us at this early stage of biological testing with $\mathrm{PhzA} / \mathrm{B}$, because we have learned from the studies with Maverick (G) that racemic ligands could offer interesting surprises with this particular protein. First we had to develop more efficient protocols for reductive aminations, as we soon noticed that all established protocols proved to be inefficient for our electron-deficient aniline substrates. In this article we want to report three methods, which proved to be very valuable for this type of substrates.

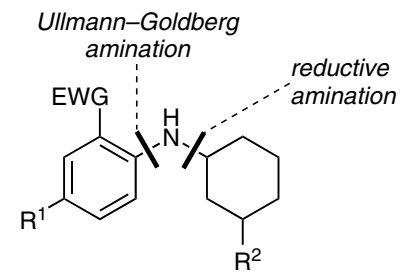

Figure 2 Strategic disconnections for the synthesis of PhzA ligands

Table 1 Screening of Reductive Amination Methods<smiles>CC(=O)c1cc(Br)ccc1[NH3+]</smiles><smiles>CC(=O)c1cc(Br)ccc1N[C@H]1CCC[C@@H](C#N)C1</smiles>

\begin{tabular}{|c|c|c|c|}
\hline Entry & Conditions & Ref. & Product formation \\
\hline 1 & $\begin{array}{l}\text { 1. toluene, } 4 \AA \text { A MS, reflux, Dean-Stark, } 4 \mathrm{~d} \\
\text { 2. } \mathrm{NaBH}_{4}\left(3 \text { equiv), MeOH, } \mathrm{N}_{2}, 20^{\circ} \mathrm{C}, 6 \mathrm{~h}\right.\end{array}$ & 14 & - \\
\hline 2 & $\begin{array}{l}\text { 1. PTSA, toluene, reflux, Dean-Stark, } 2 \mathrm{~d} \\
\text { 2. } \mathrm{NaBH}_{4} \text { ( } 3 \text { equiv), } \mathrm{MeOH}, \mathrm{N}_{2}, 20^{\circ} \mathrm{C}, 6 \mathrm{~h}\end{array}$ & - & - \\
\hline 3 & $\mathrm{TiCl}_{4}$ (0.5 equiv), $\mathrm{Et}_{3} \mathrm{~N}$ (2.0 equiv), $\mathrm{CH}_{2} \mathrm{Cl}_{2}, 20^{\circ} \mathrm{C}, 4 \mathrm{~d}$ & 15 & - \\
\hline 4 & $\begin{array}{l}\text { 1. } \mathrm{Ti}\left(\mathrm{O}^{\prime} \mathrm{Pr}\right)_{4} \text {, neat, } 20^{\circ} \mathrm{C}, 1 \mathrm{~h} \\
\text { 2. } \mathrm{NaCNBH}_{3}\left(0.55 \text { equiv), EtOH, } 20^{\circ} \mathrm{C}, 3 \mathrm{~d}\right.\end{array}$ & 16 & - \\
\hline 5 & $\begin{array}{l}\text { 1. } \mathrm{Ti}\left(\mathrm{O}^{\mathrm{P} P r}\right)_{4}\left(1.25 \text { equiv), neat, } 40^{\circ} \mathrm{C}, 16 \mathrm{~h}\right. \\
\text { 2. } \mathrm{NaBH}_{4}\left(2 \text { equiv), } 0-20^{\circ} \mathrm{C}, \mathrm{EtOH}, 6 \mathrm{~h}\right.\end{array}$ & 17 & - \\
\hline 6 & $\begin{array}{l}\text { 1. } \mathrm{Ti}\left(\mathrm{O}^{\mathrm{P} P r}\right)_{4}\left(1.25 \text { equiv), neat, } 40^{\circ} \mathrm{C}, 16 \mathrm{~h}\right. \\
\text { 2. } \mathrm{PMHS}\left(2 \text { equiv), } 0-20^{\circ} \mathrm{C}, \mathrm{THF}, 6 \mathrm{~h}\right.\end{array}$ & 18 & - \\
\hline 9 & $\mathrm{NaBH}(\mathrm{OAC})_{3}$ (2 equiv), $\mathrm{HC}(\mathrm{OEt})_{3}-\mathrm{CH}_{2} \mathrm{Cl}{ }_{2}, 1: 1,20^{\circ} \mathrm{C}, 23 \mathrm{~h}$ & 19 & - \\
\hline 10 & $\begin{array}{l}\text { 1. } \mathrm{Na}_{2} \mathrm{SO}_{4}\left(10 \text { equiv), } \mathrm{AcOH}, 20^{\circ} \mathrm{C}, 40 \mathrm{~min}\right. \\
\text { 2. } \mathrm{NaBH}(\mathrm{OAc})_{3} \text { ( } 3 \text { equiv), } 20^{\circ} \mathrm{C}, 24 \mathrm{~h}\end{array}$ & 20 & 0 \\
\hline 11 & $\mathrm{NaBH}(\mathrm{OAC})_{3}$ (2 equiv), $\mathrm{AcOH}$ ( 1 equiv), toluene, $20^{\circ} \mathrm{C}, 6 \mathrm{~d}$ & 21 & 0 \\
\hline 12 & $\mathrm{NaBH}(\mathrm{OAc})_{3}$ (2.8 equiv), $\mathrm{AcOH}$ (5 equiv), DCE, $20^{\circ} \mathrm{C}, 30 \mathrm{~h}^{\mathrm{b}}$ & $5 b$ & + \\
\hline 13 & Hantzsch ester ( 1.5 equiv), thiourea ( 0.1 equiv), $4 \AA$ MS, toluene, $50^{\circ} \mathrm{C}, 20 \mathrm{~h}$ & $7 \mathrm{~b}$ & + \\
\hline 14 & 1.5 equiv $\mathrm{BH}_{3} \cdot \mathrm{THF}, \mathrm{CH}_{2} \mathrm{Cl}_{2}-\mathrm{AcOH}, 2: 1,20^{\circ} \mathrm{C}, 3 \mathrm{~d}$ & $9 b$ & ++ \\
\hline
\end{tabular}

a Key: - no conversion, 0 moderate conversion, + good conversion, ++ full conversion.

${ }^{\mathrm{b}}$ Methyl 3-oxocyclohexane-1-carboxylate was used as the ketone. 


\section{Results and Discussion}

Reductive amination is one of the most frequently used synthetic reactions for the production of secondary (and tertiary) amines. ${ }^{5-9}$ The advantages over other transformations are the ready accessibility of the starting materials and its selectivity avoiding overalkylation. A comprehensive review has been published in $2002,{ }^{10}$ in which the reaction with sterically congested ketone substrates and the reductive amination with electron-deficient amine nucleophiles have been defined as the remaining challenges in this field. The problematic step is often the initial imine formation due to the unreactive nature of either the carbonyl or amine component. Specific examples which have been described as test cases are the reaction of 2,6-disubstituted anilines with aldehydes ${ }^{11}$ and aliphatic or alicyclic ketones, ${ }^{5 \mathrm{~b}}$ of camphor with benzylamine, ${ }^{5 \mathrm{~b}}$ and the reaction of a $\beta$-keto ester with 2 -fluoroaniline ${ }^{12}$ (modest yield). Several methods which perform well specifically for the reductive amination of electron-deficient amines have been published. ${ }^{5 b, c, e-g, 13}$ We tested several of these methods for the reductive amination of methyl 2-amino-5-bromobenzoate and 3-oxocyclohexane-1-carbonitrile as model substrates (Table 1). ${ }^{5 b, 7 b, 9 b, 14-21}$ Most reactions failed or gave only low conversions of the starting materials due to the unreactive nature of the aromatic amine.

The methods which worked best for the synthesis of the phenazistatin A derivative in these initial screenings (Table 1 ) were investigated in detail. For further optimization the model reaction was simplified to methyl anthranilate and cyclohexanone (commercially available) and the reactions were repeated using the same procedures as described in Table 1 (entries 12-14). The results are listed in Table 2 (vide infra). The well-established $\mathrm{NaBH}(\mathrm{OAc})_{3}$ (STAB) method by Abdel-Magid, ${ }^{5 b}$ led to incomplete conversion of methyl anthranilate to the product 4 even after one week of reaction time (Table 2, entry 1 ). The transfer hydrogenation approach by Menche using the Hantzsch ester as hydride source and a thiourea organocatalyst, ${ }^{7 \mathrm{~b}}$ resulted in full conversion after six days at $50{ }^{\circ} \mathrm{C}$ (entry 2 ). The third method was the reductive amination using $\mathrm{BH}_{3} \cdot \mathrm{THF}^{9 \mathrm{~b}}$ (or $\left.\mathrm{BH}_{3} \cdot \mathrm{SMe}_{2}\right)^{9 \mathrm{C}}$ in $\mathrm{CH}_{2} \mathrm{Cl}_{2} / \mathrm{AcOH}$ at room temperature, which has been described to enable the reaction of the very electron-deficient 2-nitroaniline with acetone ( 3 equiv) in excellent yields within $16-20$ hours. However, our attempts to apply the non-optimized method for our model reaction led only to incomplete conversion. We observed that prolonged reaction time and increased carbonyl loading did not improve conversion, but increasing the amount of reductant ultimately led to full conversion. In our experience, a minimum of three equivalents of $\mathrm{BH}_{3}$. THF is needed to ensure full conversion for most substrates. When exploring the scope of this useful transformation with other sub- strates, optimized method A (1.5 equiv carbonyl substrate, 3 equiv $\mathrm{BH}_{3}$.THF) proved to be a reliable and versatile method for the reductive amination of a wide range of electrondeficient amines (entry 3). The detailed substrate scope will be described in the following sections.

Table 2 Comparison of the Reported Reductive Amination Methods with Established Protocols

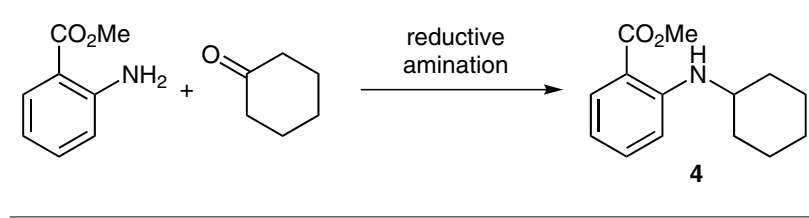

\begin{tabular}{llcccc}
\hline Entry & Method & Temp & Time & $\begin{array}{l}\text { Conversion } \\
(\%)\end{array}$ & $\begin{array}{l}\text { Yield } \\
(\%)^{\mathrm{a}}\end{array}$ \\
\hline 1 & $\mathrm{NaBH}(\mathrm{OAC})_{3}{ }^{\mathrm{b}}$ & $20{ }^{\circ} \mathrm{C}$ & $7 \mathrm{~d}$ & $77^{\mathrm{c}}$ & 73 \\
2 & Hantzsch ester $^{\mathrm{d}}$ & $50{ }^{\circ} \mathrm{C}$ & $6 \mathrm{~d}$ & 100 & 91 \\
3 & $\mathrm{~A}^{\mathrm{e}}$ & $0{ }^{\circ} \mathrm{C}$ & $3 \mathrm{~h}$ & 100 & 80 \\
4 & $\mathrm{~B}^{\mathrm{f}}$ & $0{ }^{\circ} \mathrm{C}$ & $15 \mathrm{~min}$ & 100 & 97 \\
5 & $\mathrm{C}^{\mathrm{g}}$ & $0{ }^{\circ} \mathrm{C}$ & $15 \mathrm{~min}$ & 100 & 99 \\
\hline
\end{tabular}

a Isolated yield.

${ }^{\mathrm{b}}$ According to Abdel-Magid et al.:5b aniline (1.0 equiv), ketone (2.0 equiv), $\mathrm{AcOH}$ ( 5 equiv), $\mathrm{NaBH}(\mathrm{OAC})_{3}\left(2.8\right.$ equiv), DCE, $20^{\circ} \mathrm{C}$.

c $n$-Nonane was used as an internal standard.

${ }^{\mathrm{d}}$ According to Menche et al.: ${ }^{7 \mathrm{~b}}$ aniline (1.0 equiv), cyclohexanone (1.5 equiv), Hantzsch ester ( 1.5 equiv), thiourea ( 0.1 equiv), $5 \AA$ MS, toluene, $50{ }^{\circ} \mathrm{C}$. e Method A: amine (1.00 mmol), cyclohexanone (1.50 mmol), $\mathrm{BH}_{3} \cdot \mathrm{THF}(3.0$ mmol, 3.0 equiv), $\mathrm{CH}_{2} \mathrm{Cl}_{2}-\mathrm{AcOH}, 2: 1,0-20{ }^{\circ} \mathrm{C}$.

${ }_{\mathrm{f}}$ Method B: amine ( $300 \mu \mathrm{mol}, 1.0$ equiv), cyclohexanone $(330 \mu \mathrm{mol}, 1.1$ equiv), TMSCl (750 $\mu \mathrm{mol}, 2.5$ equiv), $\mathrm{BH}_{3} \cdot \operatorname{THF}\left(300 \mu \mathrm{mol}, 1.0\right.$ equiv), DMF, $0{ }^{\circ} \mathrm{C}$. ${ }^{9}$ Method C: amine (300 $\mu \mathrm{mol}, 1.0$ equiv), cyclohexanone $(330 \mu \mathrm{mol}, 1.1$

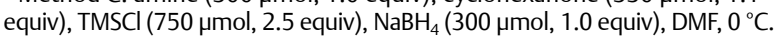

When applying method A for the synthesis of various Phenazistatin derivatives using substituted arylamines and cyclohexanones, we sometimes obtained lower yields and noticed the formation of two byproducts, namely $\mathrm{N}$-acetylated and $\mathrm{N}$-ethylated aniline substrate (Scheme 2). Such byproducts have been previously reported for the $\mathrm{NaBH}(\mathrm{OAc})_{3}$ method by Abdel-Magid ${ }^{5 b}$ when $\mathrm{AcOH}$ was used as Lewis acid. In fact, protocols for the $\mathrm{N}$-ethylation of amines using $\mathrm{NaBH}_{4}$ in neat carboxylic acid have been reported in the literature. ${ }^{22-24}$ It is suggested that the product originates from a stepwise process in which acetic acid is reduced to acetaldehyde (or an acetaldehyde equivalent), which reacts with the amine to form an iminium ion. Reduction of this imine results in the ethylamine product. ${ }^{22}$ Marchini could isolate the $\mathrm{N}$-acetylated product by heating the $\mathrm{NaBH}_{4}$-carboxylic acid mixture before addition of the amine. ${ }^{24}$ During the synthesis of Phenazistatin derivative $\mathbf{1}$, we observed the formation of these byproducts ( 2 and $\mathbf{3}$ ), which accounted for considerable consumption of the substrate arylamine (Scheme 2). 


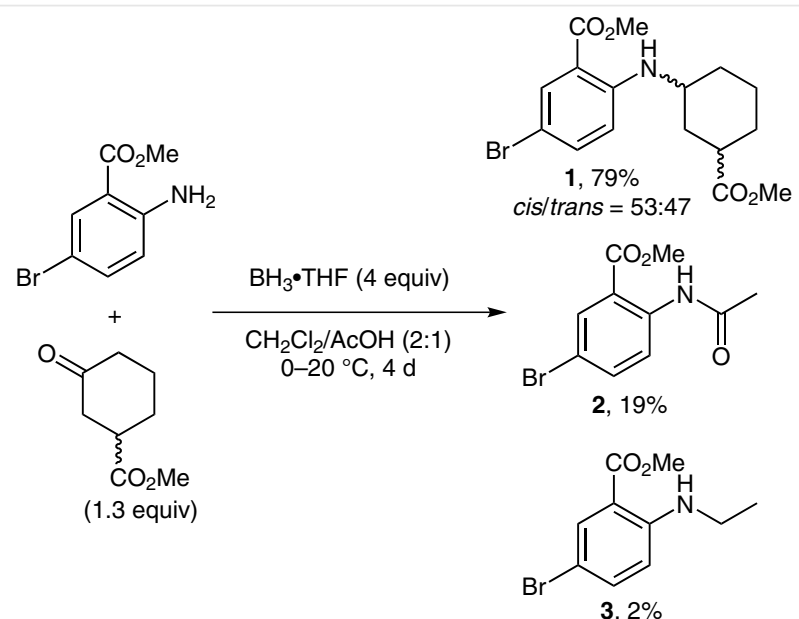

Scheme 2 Observed byproduct formation in the synthesis of a Phenazistatin derivative (percentages refer to GC-MS peak areas)

We reasoned that by using a different acid additive we might suppress these side reactions and increase the yields. Full conversion was obtained with the acids ( 9 equiv each) TFA (12 h), $\mathrm{MeSO}_{3} \mathrm{H}(3 \mathrm{~d})$, malonic acid (13 h), and phenylphosphonic acid $(13 \mathrm{~h})$ and the activating agent TMSCl (12 h) for the reaction of 2-aminobenzonitrile and 4-tert-butylcyclohexanone in rates similar to $\mathrm{AcOH}(12 \mathrm{~h})$. Among these reagents, TMSCl proved to be the most attractive substitute for AcOH due to its availability, low molecular weight, low price, and, most importantly, by its lack of the formation of the common byproducts mentioned above for $\mathrm{AcOH}$. TMSCl has been used extensively in combination with boranes for the reduction of carbonyl substrates, along with borohydrides mainly for the in situ generation of borane. ${ }^{25}$ Blacklock had used TMSCl as an additive for the reductive alkylation of ureas, thioureas, and carbamates (with benzaldehydes, $\mathrm{NaBH}_{4}$ in $\left.\mathrm{AcOH}\right){ }^{26}$ By screening different solvents we observed that DMF increases the reaction rate significantly and lowers the extent of carbonyl reduction. Optimization of the reaction parameters resulted in optimized method B (1.1 equiv carbonyl substrate, 2.5 equiv TMSCl, 1.0 equiv $\mathrm{BH}_{3} \cdot \mathrm{THF}$ ), which gave $97 \%$ yield in 15 minutes at $0{ }^{\circ} \mathrm{C}$ for the model reaction (Table 2, entry 4 ). It is noteworthy that the reaction proceeds to completion within minutes at $0{ }^{\circ} \mathrm{C}$. An amount of 1.0 equiv of $\mathrm{BH}_{3}$.THF sufficed for all tested reactions, but full conversion was detected for the reaction of 2aminobenzonitrile with cyclohexanone even when only 0.5 equiv $\mathrm{BH}_{3}$. THF was used. The reductive amination was carried out at high concentrations of the arylamine in DMF $(1.5 \mathrm{M})$ but was found to perform equally well in higher dilutions $(0.5 \mathrm{M})$. We kept the solvent volume at a minimum to facilitate the removal of DMF during workup.

One parameter which requires special attention is the reducing agent borane-tetrahydrofuran complex. $\mathrm{BH}_{3}$. THF is commonly used as a $1.0 \mathrm{M}$ solution in THF (stabilized with $\left.\mathrm{NaBH}_{4}\right),{ }^{27}$ which is stable when stored and used at 0
${ }^{\circ} \mathrm{C}$, but loses hydride activity when kept at room temperature, creating a stability and safety concern. ${ }^{27,28}$ While $\mathrm{BH}_{3}$. THF can be conveniently handled in a research laboratory, it would be desirable to substitute $\mathrm{BH}_{3}$.THF by a more inexpensive and inherently safer reducing agent for largescale applications. ${ }^{28 d, e}$ We conducted a screening of commonly employed hydride sources in combination with TMSCl as activating agent (Table 3 ).

Table 3 Test Reaction with Different Hydride Sources

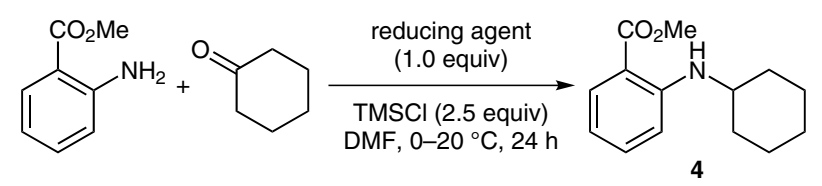

\begin{tabular}{|c|c|c|c|c|}
\hline Entry & Reducing agent & Conversion (\%) & Yield $(\%)^{b}$ & Price $[€ / \mathrm{mol} \mathrm{H}]^{\mathrm{c}}$ \\
\hline 1 & PMHS & 0 & - & 14 \\
\hline 2 & $\mathrm{Et}_{3} \mathrm{SiH}$ & 0 & - & 108 \\
\hline 3 & $\mathrm{PhSiH}_{3}$ & 100 & 84 & 218 \\
\hline 4 & $\mathrm{NaBH}_{4}$ & 100 & 88 & 6 \\
\hline 5 & $\mathrm{NaBH}(\mathrm{OAC})_{3}$ & 92 & 66 & 207 \\
\hline 6 & $\mathrm{BH}_{3} \cdot \mathrm{THF}^{\mathrm{d}}$ & 100 & 90 & 64 \\
\hline 7 & pinacolborane & 100 & 91 & 350 \\
\hline 8 & 9-BBNe & 88 & 81 & 496 \\
\hline 9 & catecholborane & 77 & 73 & 727 \\
\hline
\end{tabular}

a 1,2-DME was used as an internal standard.

b Isolated yield.

c Prices from Sigma-Aldrich catalog November 2015.

d $1.0 \mathrm{M}$ solution in THF.

e $0.5 \mathrm{M}$ solution in THF.

PMHS and $\mathrm{Et}_{3} \mathrm{SiH}$ did not react under the reaction conditions of method $\mathrm{B}$ (Table 3, entries 1 and 2), while $\mathrm{PhSiH}_{3}$ and the boron-based reductants resulted in good to high conversions and yields (entries 3-9). To our delight, $\mathrm{NaBH}_{4}$ performed equally well compared to $\mathrm{BH}_{3}$.THF in the reductive amination (entries 4 and 6), allowing us to define the cost-efficient method $\mathrm{C}\left(\mathrm{TMSCl}, \mathrm{NaBH}_{4}, \mathrm{DMF}, 0{ }^{\circ} \mathrm{C}\right.$ ), as the price per hydride equivalent of $\mathrm{NaBH}_{4}$ is significantly lower than for any other active reductant, with $\mathrm{BH}_{3}$.THF the second least expensive one. In order to explore the substrate scope, we conducted a series of experiments using method C. The results are summarized in the following section. In Table 2 we have compared the performance of the best established procedures in the literature with our new methods A-C for the same test substrate. Methods A-C deliver product $\mathbf{4}$ in much shorter reaction times and lower reaction temperatures.

So far, all reported reactions have been performed in an anhydrous solvent under inert conditions. To test the sensitivity of method $\mathrm{C}$ towards moisture and air, we performed the reaction of methyl anthranilate with cyclohexanone in an open flask using synthesis-grade (99.8\%) DMF. We were 
pleased to find that the same yield as for the inert conditions was isolated after 15 minutes reaction time at $0{ }^{\circ} \mathrm{C}$ (see below, Table 4, entry 7C*).

On the basis of previous studies by Abdel-Magid, ${ }^{5 a}$ Borch, ${ }^{29 a}$ Roth, ${ }^{6 e}$ and Schellenberg, ${ }^{29 b}$ we propose a possible mechanism outlined in Scheme 3, suggesting a dual role of TMSCl. First, TMSCl activates the carbonyl substrate for nucleophilic attack by the amine. Second, it shifts the equilibrium to the imine by serving as a dehydrating agent, ${ }^{25 \mathrm{~g}}$ which also provides the acid required for the formation of the iminium ion, which is the ultimate substrate for hydride attack (Scheme 3).
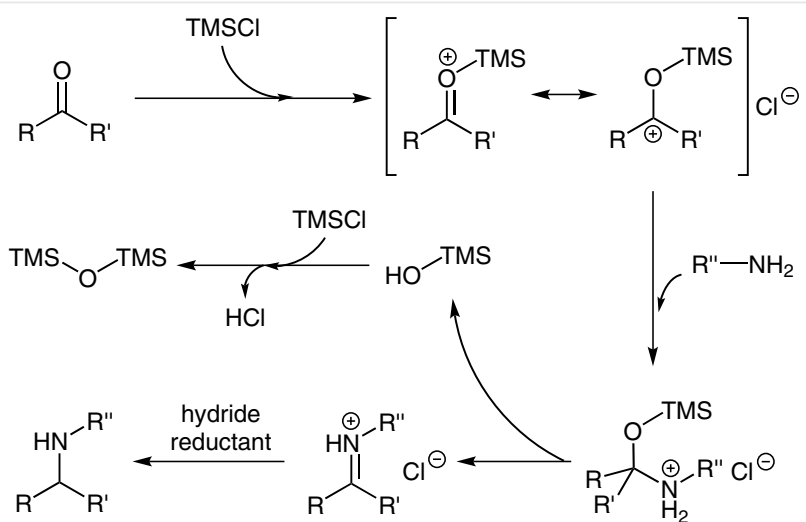

Scheme 3 Proposed mechanism of the reductive amination process

\section{Reductive Amination with Weakly Nucleophilic Amines}

The described methods are very efficient in reductive amination reactions with weakly basic and nonbasic amines. The results in Table 4 show that a wide range of arylamines can successfully react in the reductive amination with cyclohexanone. The reductive amination following the $\mathrm{BH}_{3} \cdot \mathrm{THF} / \mathrm{AcOH} / \mathrm{CH}_{2} \mathrm{Cl}_{2}$ method (Table 4, method A) with reaction times from 3-41 hours is generally slower than the $\mathrm{BH}_{3} \cdot \mathrm{THF} / \mathrm{TMSCl} / \mathrm{DMF}$ method (Table 4, method $\mathrm{B}$ ) and the $\mathrm{NaBH}_{4} / \mathrm{TMSCl} / \mathrm{DMF}$ method (Table 4, method C), which typically require 10-230 minutes. It is noteworthy that method $\mathrm{B}$ and method $\mathrm{C}$ proceed at $0{ }^{\circ} \mathrm{C}$ within minutes while method $A$ and other described methods for electron-deficient aromatic amines require room or even higher temperatures and reaction times of hours to days. We found that method $\mathrm{B}\left(\mathrm{BH}_{3} \cdot \mathrm{THF} / \mathrm{DMF}\right)$ and method $\mathrm{C}$ $\left(\mathrm{NaBH}_{4} / \mathrm{DMF}\right)$ yielded comparable results for most of the aromatic amines tested; however, method $\mathrm{B}\left(\mathrm{BH}_{3} \cdot \mathrm{THF} / \mathrm{DMF}\right)$ was chosen for the study of reactive carbonyl groups in the next section (see below, Table 5), as the handling of the liquid $\mathrm{BH}_{3}$.THF solution was more suitable for parallel operations on a small scale. While there is a significant difference between method $\mathrm{A}$ and method $\mathrm{B} /$ method $\mathrm{C}$ in matters of

reactivity and reaction rate, we observed that the selectivity and tolerance for functional groups seem to be conserved in most cases.

Table 4 Investigation of the Aniline Substrate Scope for Reductive Amination by Methods $\mathrm{A}, \mathrm{B}$, and $\mathrm{C}$
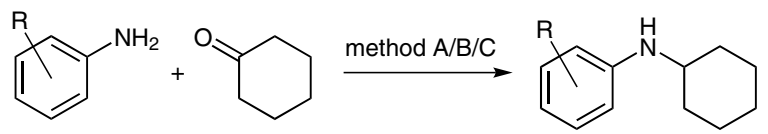

method A: amine (1 equiv), ketone (1.5 equiv), $\mathrm{BH}_{3} \cdot \mathrm{THF}$ (3 equiv), $\mathrm{CH}_{2} \mathrm{Cl}_{2} / \mathrm{AcOH}^{\mathrm{a}}$

method $B$ : amine (1 equiv), ketone (1.1 equiv), TMSCl (2.5 equiv), $\mathrm{BH}_{3} \cdot \mathrm{THF}$ (1 equiv), $\mathrm{DMF}^{\mathrm{b}}$

method C: amine ( 1 equiv), ketone (1.1 equiv), TMSCl (2.5 equiv), $\mathrm{NaBH}_{4}$ (1 equiv), $\mathrm{DMF}^{\mathrm{C}}$

Amine $\quad$ Product Entry Method $^{\mathrm{a}-\mathrm{c}}$ Time $\quad$ Yield<smiles>COc1ccccc1N</smiles>

5<smiles>CCCc1cccc(Br)c1N</smiles><smiles>Nc1ccccc1</smiles>
7<smiles>CCOP(=O)(OCC)c1ccccc1N</smiles>
8$$
\begin{aligned}
& 4 \mathrm{~A} \\
& 4 \mathrm{~B}
\end{aligned}
$$

A
B

$3 \mathrm{~h}$ 10 min<smiles>Nc1c(Cl)cccc1Cl</smiles>
9 $5 A$
$5 B$
$5 C$

$A$
$B^{f}$
$C$

$6 \mathrm{~d}$ $18 \mathrm{~min}$ $\left(18^{\mathrm{h}}\right)$ 90
87<smiles>Nc1ccccc1C(=O)O</smiles>
10

$6 \mathrm{~B}$
$6 \mathrm{C}$

B

$10 \mathrm{~min}$ 15 min<smiles>COC(=O)c1ccccc1N</smiles>
4

$7 \mathrm{~A}$
$7 \mathrm{~B}$
$7 \mathrm{C}$
$7 \mathrm{C}^{*}$

$3 \mathrm{~h}$ $15 \mathrm{~min}$ $15 \mathrm{~min}$ 80 97 99 99<smiles>CC(=O)c1ccc(N)cc1</smiles>
11

81
85
90


0
$66^{9}$
0


77
77
70


Table 4 (continued)

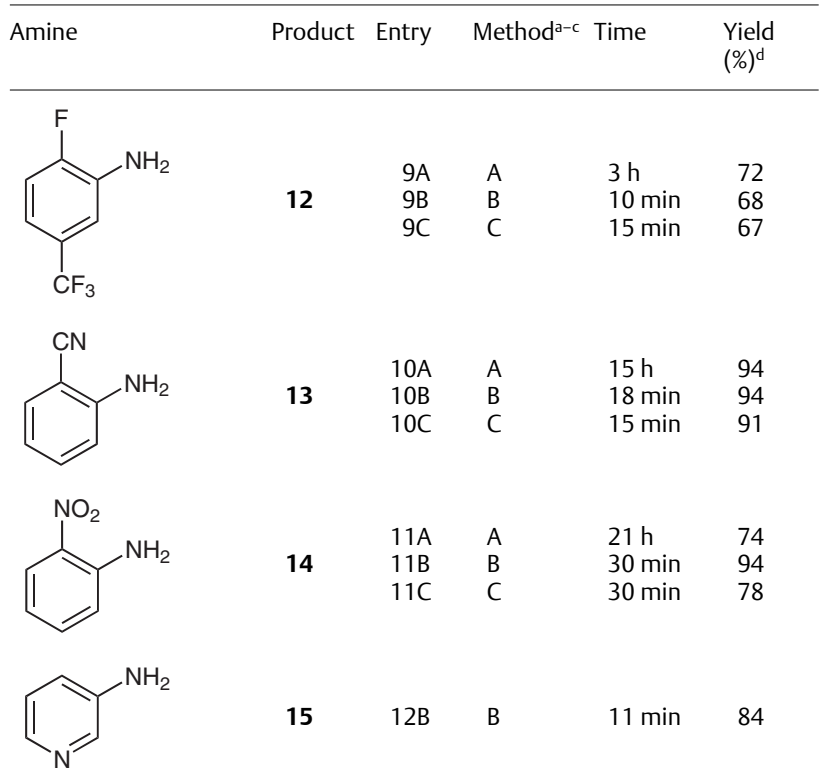

a Method A: amine (1.00 mmol), cyclohexanone $(1.50 \mathrm{mmol}), \mathrm{BH}_{3} \cdot \mathrm{THF}$ (3.0 mmol, 3.0 equiv), $\mathrm{CH}_{2} \mathrm{Cl}_{2}-\mathrm{AcOH}, 2: 1,0-20^{\circ} \mathrm{C}$

b Method B: amine ( $300 \mu \mathrm{mol}, 1.0$ equiv), cyclohexanone $(330 \mu \mathrm{mol}, 1.1$ equiv), TMSCl (750 $\mu \mathrm{mol}, 2.5$ equiv), $\mathrm{BH}_{3} \cdot \operatorname{THF}$ ( $300 \mu \mathrm{mol}, 1.0$ equiv), DMF, 0 ${ }^{\circ} \mathrm{C}$.

'Method C: amine (300 $\mu \mathrm{mol}, 1.0$ equiv), cyclohexanone (330 $\mu \mathrm{mol}, 1.1$ equiv), TMSCl (750 $\mu$ mol, 2.5 equiv), $\mathrm{NaBH}_{4}$ (300 $\mu \mathrm{mol}, 1.0$ equiv), DMF, 0

IIsolated yield.

e TMSOTf was used instead of TMSCl.

${ }^{f}$ Cyclohexanone (1.5 equiv) was used.

${ }^{9}$ Carbonyl reduction was observed.

${ }^{h}$ Conversion of the starting material ( $n$-nonane used as internal standard).

i Performed in an open flask using synthesis-grade DMF (99.8\%).

One case in which the selectivity differs between method $A$ and method $B$ is found in the reductive amination of 4acetylaniline. Method $A$ gives the product 11 in low yields (Table 4, entry 8A), due to a large amount of self-condensation of the aromatic ketone with the aniline, whereas with method $\mathrm{B}$ the aromatic ketone moiety remains untouched and the product $\mathbf{1 1}$ is obtained in good yield (entry 8B).

The described methods give good yields for electronrich primary anilines and a wide range of electron-deficient primary aromatic amines. The reactions are convenient and simple and show a high degree of tolerance for a variety of functional groups including acetyl, alkoxycarbonyl, carboxy, cyano, diethylphosphonyl, halo, and nitro groups.

Substitution at the ortho position of aromatic amines did not seem to have any detrimental effect on the reaction rate, and high to excellent yields were obtained (Table 4). As mentioned above, the reductive amination of 2,6-disubstituted anilines has been described in the literature as a challenging substrate combination..$^{5,10}$ The sterically hindered 2,6-dichloroaniline reacted very slowly by method A (entry $5 \mathrm{~A}, 18 \%$ conversion after $6 \mathrm{~d}$ ), but to our delight reacted smoothly by method B and method C, giving product $\mathbf{9}$ in
90\% and $87 \%$ yield (entries $5 \mathrm{~B}$ and $5 \mathrm{C}$ ), respectively. The most sterically hindered aniline used, 2,6-diisopropylaniline, failed to undergo reaction with cyclohexanone by both methods $\mathrm{B}$ and $\mathrm{C}$ (entries $2 \mathrm{~B}$ and $2 \mathrm{C}$ ). However, the reactivity of method $B$ could be enhanced by the use of TMSOTf instead of TMSCl (entry $2 \mathrm{~B}^{*}$ ). The reaction proceeded very slowly ( $230 \mathrm{~min}$ ) but gave the product $\mathbf{6}$ in $66 \%$ yield.

The very electron-deficient 2-nitroaniline gave product 14 in $94 \%$ yield after $30 \mathrm{~min}$ at $0{ }^{\circ} \mathrm{C}$ by method B (Table 4 , entry 11B). Abdel-Magid ${ }^{5 b}$ could only obtain $30 \%$ conversion to the desired product after 6 days at room temperature when using the optimized $\mathrm{NaBH}(\mathrm{OAc})_{3}$ conditions. Anthranilic acid reacted well by methods $A$ and $B$ to give product 10 in 91\% yield (entries 6B and 6C). Interestingly, the heterocyclic arylamine 3-aminopyridine reacted to form the reductive amination product $\mathbf{1 5}$ in $84 \%$ yield by method B (entry 12B).

\section{Reductive Amination of Aldehydes and Ketones}

The results in Table 5 show that the reductive amination of a variety of aromatic aldehydes as well as cyclic and acyclic ketones with the electron-deficient anilines $\mathbf{H}$ and $\mathbf{I}$ was successfully accomplished under the standard conditions (methods A and B) and furnished the products in moderate to excellent yields. The scope of the reaction includes different aromatic aldehydes (entries $1 \mathrm{~A}, 1 \mathrm{~B}$, and $2 \mathrm{~B}$ ), cinnamic aldehyde (entry 3B), alicyclic ketones (entries 5A, 8A, 9A, and 4B-9B), 2-adamantanone (entries 9A and 9B), saturated acyclic ketones (entries 10A, 11A, 11B, 12B, and 13B*), methyl 3-oxobutanoate (entry 12B), acetophenone (entries $16 \mathrm{~A}$ and $16 \mathrm{~B}^{*}$ ) and 1,1-diethoxycyclohexane (entry 18B). For the same primary aromatic amine the rate of the reaction was dependent on the steric and electronic factors associated with the carbonyl substrates as well as with the reductive amination protocol used. The substrates reacted consistently more sluggishly when using the $\mathrm{BH}_{3}$.THF in $\mathrm{CH}_{2} \mathrm{Cl}_{2} / \mathrm{AcOH}$ system (method $\mathrm{A}$ ) as compared to the $\mathrm{BH}_{3} \cdot \mathrm{THF} / \mathrm{TMSCl} / \mathrm{DMF}$ system (method B).

Aldehydes and ketones are known to be reduced by $\mathrm{BH}_{3} \cdot \mathrm{THF}^{30}$ and $\mathrm{NaBH}_{4},{ }^{31}$ and thus carbonyl reduction could be expected to compete with the reductive amination process. ${ }^{5 b}$ However, the chosen reaction conditions were so selective that the reductive amination with aldehydes and ketones worked efficiently and resulted in clean reactions in most cases. Cases in which carbonyl reduction was detected involved the sterically hindered 2-tert-butylcyclohexan-1one in both methods A and B (Table 5, entries 14A, 14B, and $14 \mathrm{~B}^{*}$ ), 2,6-diisopropylaniline in the modified method $\mathrm{B}$ (Table 4 , entry $\left.2 \mathrm{~B}^{*}\right)$, and acetophenone when using the modified method $\mathrm{B}$ (Table 5 , entry $16 \mathrm{~B}^{*}$ ).

Of all the carbonyl substrates used in this study, the alicyclic ketones were the most reactive and gave very good to excellent yields (Table 5, entries 5A-9A and 4B-9B). Aldehydes gave somewhat lower yields with comparable reac- 
tion times (entries $1 \mathrm{~A}$ and $1 \mathrm{~B}-3 \mathrm{~B}$ ), but, in contrast to established silane-based methods, we did not observe any overalkylated products. trans-Cinnamaldehyde reacted smoothly with methyl anthranilate providing 19 in $81 \%$ yield with no trace of $\mathrm{C}=\mathrm{C}$ reduction product (entry $3 \mathrm{~B}$ ), which is a common side reaction with borane reagents. Saturated acyclic ketones reacted more sluggishly and gave lower yields (entries $10 \mathrm{~A}, 11 \mathrm{~A}, 11 \mathrm{~B}$, and $13 \mathrm{~B}^{*}$ ). The $\beta$-keto ester methyl 3 -oxobutanoate (entry $12 \mathrm{~B}$ ) reacted slowly and gave product 29 in 67\% yield. The acid-labile ketone 1-Boc-3-piperidone reacted well with methyl anthranilate by method $A$, producing 23 (66\%) (entry $8 A$ ), whereas method $C$ yielded a complex mixture. Method A might be the better method for the coupling of more acid-sensitive carbonyl and arylamine substrates.

Table 5 Investigation of the Carbonyl Substrate Scope for Reductive Amination by Methods A and B

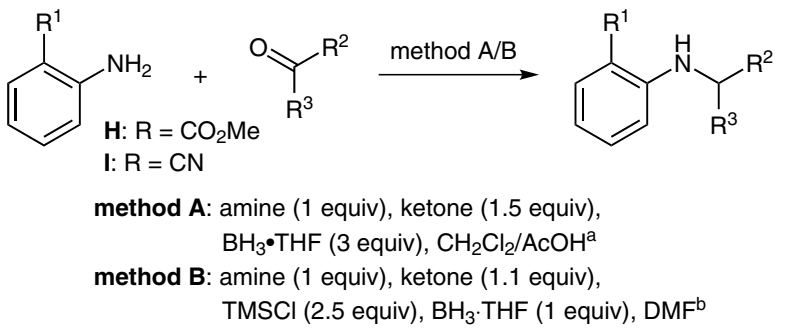

Carbonyl reagent Entry Amine Method ${ }^{\mathrm{a}, \mathrm{b}}$ Time Product Yield (\%)

$\begin{array}{lllllll}1 \mathrm{~A} & \mathrm{I} & \mathrm{A} & 15 \mathrm{~h} & \mathbf{1 6} & 80 \\ 1 \mathrm{~B} & \mathrm{H} & \mathrm{B} & 20 \mathrm{~min} & \mathbf{1 7} & 85\end{array}$

2B H $\quad$ B $\quad 10$ min $18 \quad 84$

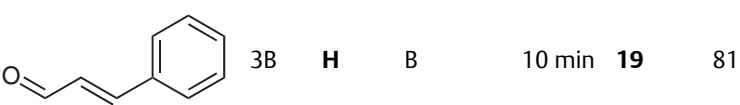

$Y \begin{array}{llllll} & 4 \mathrm{~B} & \mathrm{H} & \mathrm{B} & 15 \min 20 & 96\end{array}$

$\begin{array}{llllll}5 \mathrm{~A} & \mathrm{I} & \mathrm{A} & 15 \mathrm{~h} & \mathbf{1 3} & 94 \\ 5 \mathrm{~B} & \mathrm{H} & \mathrm{B} & 15 \mathrm{~min} & \mathbf{4} & 97\end{array}$
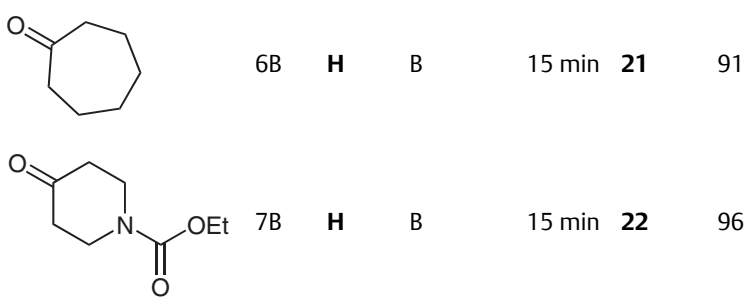

Table 5 (continued)

Carbonyl reagent Entry Amine Method ${ }^{\mathrm{a}, \mathrm{b}}$ Time Product Yield (\%)<smiles>CC(C)(C)OC(=O)N1CCCC(=O)C1</smiles><smiles>O=C1C2CC3CC(C2)CC1C3</smiles>

$\begin{array}{llllll}9 A & \text { I } & \text { A } & 41 \mathrm{~h} & \mathbf{2 4} & 80 \\ 9 B & \text { H } & \text { B } & 24 \mathrm{~min} & \mathbf{2 5} & 94\end{array}$<smiles>CCCC(C)=O</smiles>

$10 \mathrm{~A}$

A

$39 \mathrm{~h} \quad 26$

80<smiles>CC(=O)CC(C)C</smiles>

$\begin{array}{lll}11 \mathrm{~A} & \mathbf{I} & \mathrm{A} \\ 11 \mathrm{~B} & \mathbf{H} & \mathrm{B}\end{array}$

$12 \mathrm{~B} \quad \mathrm{H}$

B

29

67<smiles>CC(=O)C(C)(C)C</smiles>

$\begin{array}{lllllr}13 \mathrm{~B} & \mathbf{H} & \mathrm{B} & 17 \mathrm{~h} & - & 0 \\ 13 \mathrm{~B}^{*} & \mathbf{H} & \mathrm{B}^{\mathrm{d}, \mathrm{e}} & 20 \mathrm{~h} & \mathbf{3 0} & 50\end{array}$<smiles>O=C1CCCC[C@H]1Br</smiles>

$14 \mathrm{~A}$

$14 \mathrm{~B}^{*}$<smiles>CC12CCC(C1)C1(C)CCC2CC1=O</smiles>

$15 \mathrm{~A}$

$15 \mathrm{~B}^{*} \mathbf{H} \quad \mathrm{B}^{\mathrm{d}, \mathrm{e}} \quad 18 \mathrm{~h}-\mathrm{H}^{\mathrm{H}} \quad$ traces $^{9}$<smiles>CC(=O)c1ccccc1</smiles>

$\begin{array}{lll}16 \mathrm{~A} & \mathbf{I} & \mathrm{A} \\ 16 \mathrm{~B} & \mathbf{H} & \mathrm{B} \\ 16 \mathrm{~B}^{*} & \mathbf{H} & \mathrm{B}^{\mathrm{d},}\end{array}$

$39 \mathrm{~h}$

$31 \quad 70$ $\begin{array}{rr}31 & 70 \\ - & 0\end{array}$<smiles>O=C(c1ccccc1)c1ccccc1</smiles>

$\begin{array}{llllll}17 \mathrm{~A} & \mathbf{I} & \mathrm{A} & 4 \mathrm{~d} & - & 0 \\ 17 \mathrm{~B} & \mathbf{H} & \mathrm{B} & 17 \mathrm{~h} & - & 0\end{array}$

$17 \mathrm{~B}^{*} \mathrm{H} \quad \mathrm{B}^{\mathrm{d}, \mathrm{e}} \quad 20 \mathrm{~h} \quad-\quad$ traces $^{\mathrm{s}}$

EtO<smiles>CCOC1(OCC)CCCCC1</smiles>

$18 \mathrm{~B}$

$19 \min 4$

$71^{\mathrm{h}}$

athod A: amine $(1.0 \mathrm{mmol})$, cyclohexanone $(1.5 \mathrm{mmol}), \mathrm{BH}_{3} \cdot \mathrm{THF}(3.0$ mmol, 3.0 equiv), $\mathrm{CH}_{2} \mathrm{Cl}_{2}-\mathrm{AcOH}, 2: 1,0-20{ }^{\circ} \mathrm{C}$.

${ }^{\mathrm{b}}$ Method B: amine ( $300 \mu \mathrm{mol}, 1.0$ equiv), cyclohexanone $(330 \mu \mathrm{mol}, 1.1$ equiv), TMSCl (750 $\mu \mathrm{mol}, 2.5$ equiv), $\mathrm{BH}_{3}$. THF ( $300 \mu \mathrm{mol}, 1.0$ equiv), DMF, 0

'Isolated yield

d TMSOTf was used instead of TMSCl.

e Cyclohexanone (1.5 equiv) was used.

${ }^{f}$ Carbonyl reduction was observed.

9 Product mass was identified by GC-MS (<5\%).

${ }^{\mathrm{h}}$ Methyl 2-(cyclohexylamino)benzoate was obtained as the product. 


\section{Reductive Amination of Aromatic and Sterically Hin- dered Ketones}

The least reactive ketones were aromatic and sterically hindered alicyclic and aliphatic ketones. It is noteworthy that acetophenone reacted smoothly by method A to give the desired product $\mathbf{3 1}$ in good yield, whereas the unmodified method B failed (Table 5, entries 16A and 16B). For other unreactive carbonyl substrates, the arylamine substrate was quantitatively acetylated to the byproduct $\mathrm{N}$-(2-cyanophenyl)acetamide, as judged by GC-MS (entries 14A, 15A, and 17A). The formation of small amounts of these byproducts was also described for some slow reactions when using the established $\mathrm{NaBH}(\mathrm{OAc})_{3}$-protocol..$^{5 \mathrm{~b}}$ Benzophenone, 2-(tert-butyl)cyclohexan-1-one, and (+)-camphor failed to react with 2 -aminobenzonitrile by method $\mathrm{A}$ (entries $14 \mathrm{~A}$, $15 \mathrm{~A}$, and $17 \mathrm{~A}$ ). These substrates as well as acetophenone and benzophenone could also not be converted in the reaction with methyl anthranilate by method B (entries 13B, 14B, 15B, 16B, and 17B).

However, the reactivity could be enhanced by using the more reactive TMSOTf instead of TMSCl as demonstrated for the reaction with pinacolone and acetophenone giving the products 30 and 32 in good yields (entries $13 \mathrm{~B}^{*}$ and $16 \mathrm{~B}^{*}$ ) after reaction times of 20 and 23 hours, respectively. However, even with the TMSOTf-modified method B, the other challenging ketones hardly reacted with methyl anthranilate, and only traces $(<5 \%)$ of the desired products were detected by GC-MS (entries $14 \mathrm{~B}^{*}, 15 \mathrm{~B}^{*}$, and $17 \mathrm{~B}^{*}$ ) after 18-23 hours. Interestingly, method B can also be used for the reductive amination with ketals, as exemplified for 1,1-diethoxycyclohexane as a substrate (entry 18B).

To demonstrate the scalability of method B, the gramscale synthesis of the Phenazistatin derivatives $\mathbf{3 3}$ and $\mathbf{3 4}$ (Figure 3) was performed, which delivered 33 and 34 in 96\% and $97 \%$ yield, respectively, in the short reaction times observed for the model reactions.<smiles>COC(=O)c1cc(Br)ccc1N[C@H]1CCC[C@H](C(=O)OC)C1</smiles>

$2.70 \mathrm{~g}, 48 \mathrm{~min}$ $96 \%$<smiles>COC(=O)c1cc(I)ccc1N[C@H]1CCC[C@H](C(=O)OC)C1</smiles>

$8.61 \mathrm{~g}, 30 \mathrm{~min}$
Figure 3 Gram-scale synthesis of Phenazistatin derivatives using method B

\section{Summary and Conclusions}

In conclusion, we have established three new methods which have proven useful for the reductive amination of electron-deficient anilines with ketones. Method A
$\left(\mathrm{BH}_{3} \cdot \mathrm{THF} / \mathrm{AcOH} / \mathrm{CH}_{2} \mathrm{Cl}_{2}\right)$ is distinguished by inexpensive reagents and simple workup, but requires longer reaction times and gives rise to acetylated byproducts for substrate combinations with slow imine formation. For these substrates, the more reactive activating agent TMSCl is recommended, and both method $\mathrm{B}\left(\mathrm{BH}_{3} \cdot \mathrm{THF} / \mathrm{TMSCl} / \mathrm{DMF}\right)$ as well as method $\mathrm{C}\left(\mathrm{NaBH}_{4} / \mathrm{TMSCl} / \mathrm{DMF}\right)$ offer powerful reagent combinations, which result in full conversions for most substrates within 10-25 minutes. In case these methods fail, the use of TMSOTf offers an additional possibility to make sterically more congested substrates accessible. Together, these methods have expanded the scope of the reductive amination reaction, which will become an even more powerful tool for the organic synthesis of substituted amines.

TMSCl (98\%) and $\mathrm{BH}_{3}$.THF (1.0 M solution in THF) were purchased from Sigma Aldrich and anhyd DMF was purchased from Alfa Aesar and stored over $3 \AA$ molecular sieves in an amber $1000 \mathrm{~mL}$ Schlenk bottle. All experiments were carried out by using established Schlenk techniques. Analytical TLC was carried out on Merck TLC silica gel 60 F254 aluminum sheets and spots were visualized by UV light $(\lambda=254$ and/or $366 \mathrm{~nm}$ ) or by staining with cerium ammonium molybdate [CAM; $2.0 \mathrm{~g} \mathrm{Ce}\left(\mathrm{SO}_{4}\right)_{2}, 50.0 \mathrm{~g}\left(\mathrm{NH}_{4}\right)_{6} \mathrm{Mo}_{7} \mathrm{O}_{24}$, and $50 \mathrm{~mL}$ concd $\mathrm{H}_{2} \mathrm{SO}_{4}$ in $400 \mathrm{~mL} \mathrm{H}_{2} \mathrm{O}$ ] or potassium permanganate $\left(0.3 \mathrm{~g} \mathrm{KMnO}_{4}, 20 \mathrm{~g} \mathrm{~K}_{2} \mathrm{CO}_{3}\right.$, and $5 \mathrm{~mL} 5 \%$ aq $\mathrm{NaOH}$ in $300 \mathrm{~mL} \mathrm{H}_{2} \mathrm{O}$ ). Flash column chromatography was performed using silica gel $0.035-0.070 \mathrm{~mm}, 60 \AA$ (Acros Organics). ATR-IR spectra were recorded using an ALPHA FT-IR spectrometer (Bruker; Billerica, MA, USA). ${ }^{1} \mathrm{H}$ and ${ }^{13} \mathrm{C}$ NMR spectra were recorded on a Bruker AVANCE III 300 spectrometer $\left({ }^{1} \mathrm{H}: 300.36 \mathrm{MHz} ;{ }^{13} \mathrm{C}\right.$ : $75.53 \mathrm{MHz})$ and ${ }^{19} \mathrm{~F}(282.47 \mathrm{MHz})$ and ${ }^{31} \mathrm{P}(121.58 \mathrm{MHz})$ NMR spectra were recorded on a Varian INOVA 300 spectrometer and referenced versus TMS using the internal ${ }^{2} \mathrm{H}$-lock signal of the solvent.

\section{Method A: Reductive Amination of Arylamines and Aldehydes/} Ketones with $\mathrm{BH}_{3} \cdot \mathrm{THF}$ in $\mathrm{CH}_{2} \mathrm{Cl}_{2} / \mathbf{A c O H}$; General Procedure A

A dry $20 \mathrm{~mL}$ Schlenk tube with magnetic stirring bar was charged consecutively with arylamine (1.0 mmol, 1.0 equiv), carbonyl substrate (1.5 mmol, 1.5 equiv), anhyd $\mathrm{CH}_{2} \mathrm{Cl}_{2}(2.0 \mathrm{~mL})$, and glacial $\mathrm{AcOH}$ $(1.0 \mathrm{~mL})$ in a $\mathrm{N}_{2}$ counter-stream. The reaction mixture was cooled to 0 ${ }^{\circ} \mathrm{C}$, the glass stopper was replaced by a rubber septum, and a $1.0 \mathrm{M}$ solution of $\mathrm{BH}_{3}$.THF in THF ( $3.0 \mathrm{~mL}, 3.0 \mathrm{mmol}, 3$ equiv) was added slowly by syringe over a period of $10-20 \mathrm{~min}$. The flask was sealed with a glass stopper and the mixture was kept stirring in the thawing ice bath until full conversion was detected by TLC. The vigorously stirred mixture was cooled to $0{ }^{\circ} \mathrm{C}$ again and sat. $\mathrm{NaHCO}_{3}(5 \mathrm{~mL})$ was added carefully $\left(\mathrm{CO}_{2}\right.$ evolution!) followed by EtOAc $(10 \mathrm{~mL})$. The twophase mixture was kept stirring until the gas evolution had ceased (typically 20-60 $\mathrm{min}$ ). The phases were separated and the aqueous layer was extracted with EtOAc $(5 \times 10 \mathrm{~mL})$. The combined organic layers were dried over $\mathrm{Na}_{2} \mathrm{SO}_{4}$, the drying agent was removed by filtration, and the solvents were removed under reduced pressure. The crude product (adsorbed onto Celite) was purified by chromatography (silica gel, cyclohexane-EtOAc, gradient). 


\section{Method B: Reductive Amination of Arylamines and Aldehydes/ Ketones with $\mathrm{BH}_{3} \cdot \mathrm{THF}$ and TMSCl in DMF; General Procedure B}

A dry $20 \mathrm{~mL}$ Schlenk tube with magnetic stirring bar was charged consecutively with arylamine ( $300 \mu \mathrm{mol}, 1.0$ equiv), carbonyl substrate (330 $\mu \mathrm{mol}, 1.1$ equiv), anhyd DMF $(200 \mu \mathrm{L})$, and TMSCl $(96.8 \mu \mathrm{L}$, $750 \mu \mathrm{mol}, 2.5$ equiv) in a $\mathrm{N}_{2}$ counter-stream. The reaction mixture was cooled to $0{ }^{\circ} \mathrm{C}$, the glass stopper was replaced by a rubber septum, and a $1.0 \mathrm{M}$ solution of $\mathrm{BH}_{3}$ THF in THF ( $300 \mu \mathrm{L}, 300 \mu \mathrm{mol}, 1.0$ equiv) was added slowly with a syringe over a period of 10-20 min. The flask was sealed with a glass stopper and the reaction mixture was kept stirring at $0{ }^{\circ} \mathrm{C}$ until full conversion was detected by TLC. The vigorously stirred reaction mixture was treated with $\mathrm{H}_{2} \mathrm{O}(3 \mathrm{~mL})$ and the mixture was stirred for $20 \mathrm{~min}$. EtOAc $(5 \mathrm{~mL})$ was added followed by sat. $\mathrm{Na}_{2} \mathrm{CO}_{3}$ solution $(2.5 \mathrm{~mL})\left(\mathrm{CO}_{2}\right.$ evolution!). The twophase mixture was kept stirring until the gas evolution had ceased (typically 20-60 min). In case the aqueous phase was turbid, small amounts of $\mathrm{H}_{2} \mathrm{O}$ were added to provide a clear aqueous phase. The phases were separated and the aqueous layer was extracted with EtOAc $(5 \times 8 \mathrm{~mL})$. The combined organic layers were dried over $\mathrm{Na}_{2} \mathrm{SO}_{4}$, the drying agent was removed by filtration, and the solvents were removed under vacuum. The crude product (adsorbed onto Celite) was purified by chromatography (silica gel, cyclohexane-EtOAc, gradient).

\section{Method C: Reductive Amination of Arylamines and Aldehydes/ Ketones with $\mathrm{NaBH}_{4}$ and TMSCl in DMF; General Procedure C}

A dry $20 \mathrm{~mL}$ Schlenk tube with magnetic stirring bar was charged consecutively with arylamine (1.0 mmol, 1.0 equiv), carbonyl substrate ( $1.1 \mathrm{mmol}, 1.1$ equiv), anhyd DMF $(670 \mu \mathrm{L})$, and TMSCl (323 $\mu \mathrm{L}$, $2.5 \mathrm{mmol}, 2.5$ equiv) in a $\mathrm{N}_{2}$ counter-stream. The reaction mixture was cooled to $0{ }^{\circ} \mathrm{C}$ and $\mathrm{NaBH}_{4}(39.0 \mathrm{mg}, 1.0 \mu \mathrm{mol}, 1.0$ equiv) was added in one portion. The flask was sealed with a glass stopper and the reaction mixture was kept stirring at $0{ }^{\circ} \mathrm{C}$ until full conversion was detected by TLC. The vigorously stirred reaction mixture was treated with sat. $\mathrm{NaHCO}_{3}$ solution $(5 \mathrm{~mL})\left(\mathrm{CO}_{2}\right.$ evolution!) followed by EtOAc $(5 \mathrm{~mL})$. The two-phase mixture was kept stirring until the gas evolution had ceased (typically 20-60 min). In case the aqueous phase was turbid, small amounts of $\mathrm{H}_{2} \mathrm{O}$ were added to provide a clear aqueous phase. The phases were separated and the aqueous layer was extracted with EtOAc $(5 \times 10 \mathrm{~mL})$. The combined organic layers were dried over $\mathrm{Na}_{2} \mathrm{SO}_{4}$, the drying agent was removed by filtration, and the solvents were removed by using a rotary evaporator. The solvents were removed under vacuum and the crude product (adsorbed onto Celite) was purified by chromatography (silica gel, cyclohexane-EtOAc, gradient).

\section{Methyl 2-(Cyclohexylamino)benzoate (4)}

Prepared according to general procedure A from methyl anthranilate $(131 \mu \mathrm{L}, 1.0 \mathrm{mmol}) ; 3 \mathrm{~h}$ reaction time; purified by column chromatography (cyclohexane-EtOAc, $150: 1$, size: $11 \times 2.8 \mathrm{~cm}$ ); yield: $186 \mathrm{mg}$ (797 $\mu \mathrm{mol}, 80 \%$ ); light-yellow, viscous liquid.

Prepared according to general procedure B from methyl anthranilate (39.2 $\mu \mathrm{L}, 300 \mu \mathrm{mol}) ; 15$ min reaction time; purified by column chromatography (cyclohexane-EtOAc, 200:1, 150:1, size: $7.5 \times 2.2 \mathrm{~cm}$ ); yield: $68.2 \mathrm{mg}$ ( $292 \mu \mathrm{mol}, 97 \%)$; light-yellow, viscous liquid.

Prepared according to general procedure B from methyl anthranilate (39.2 $\mu \mathrm{L}, 300 \mu \mathrm{mol})$ and 1,1-diethoxycyclohexane $(64.5 \mu \mathrm{L}, 330$ $\mu \mathrm{mol}) ; 19$ min reaction time; purified by column chromatography (cyclohexane-EtOAc, 150:1, size: $8 \times 0.8 \mathrm{~cm})$; yield: $49.4 \mathrm{mg}(212$ $\mu \mathrm{mol}, 71 \%)$; light-yellow, viscous liquid.
Prepared according to general procedure $C$ from methyl anthranilate (39. $2 \mu \mathrm{L}, 300 \mu \mathrm{mol}) ; 15 \mathrm{~min}$ reaction time; purified by column chromatography (cyclohexane-EtOAc, 200:1, 150:1, size: $7.5 \times 2.2 \mathrm{~cm}$ ); yield: $69.1 \mathrm{mg}$ (296 $\mu \mathrm{mol}, 99 \%)$; light-yellow, viscous liquid.

$R_{f}=0.67$ (cyclohexane-EtOAc, 8:1) (254 nm, $366 \mathrm{~nm}$, CAM: orange). IR (ATR): 3346, 2928, 2852, 1680, 1606, 1579, 1516, 1436, 1328, 1249, 1223, 1187, 1161, 1137, 1107, 1075, 1045, 745, 702, 565, $525 \mathrm{~cm}^{-1}$.

${ }^{1} \mathrm{H}$ NMR $\left(300 \mathrm{MHz}, \mathrm{CDCl}_{3}\right): \delta=7.93-7.84(\mathrm{~m}, 1 \mathrm{H}, \mathrm{ArH}), 7.82-7.69(\mathrm{~m}$, $1 \mathrm{H}, \mathrm{NH}), 7.36-7.21(\mathrm{~m}, 1 \mathrm{H}, \mathrm{ArH}), 6.74-6.63(\mathrm{~m}, 1 \mathrm{H}, \mathrm{ArH}), 6.56-6.45$ (m, $1 \mathrm{H}, \mathrm{ArH}), 3.84\left(\mathrm{~s}, 3 \mathrm{H}, \mathrm{CH}_{3}\right), 3.47-3.30(\mathrm{~m}, 1 \mathrm{H}, \mathrm{CH}), 2.10-1.94(\mathrm{~m}$, $\left.2 \mathrm{H}, \mathrm{CH}_{2}\right), 1.84-1.69\left(\mathrm{~m}, 2 \mathrm{H}, \mathrm{CH}_{2}\right), 1.67-1.53\left(\mathrm{~m}, 1 \mathrm{H}, \mathrm{CH}_{2}\right), 1.49-1.20$ $\left(\mathrm{m}, 5 \mathrm{H}, \mathrm{CH}_{2}\right.$ ).

${ }^{13} \mathrm{C}$ NMR $\left(75.53 \mathrm{MHz}, \mathrm{CDCl}_{3}\right): \delta=169.3\left(\mathrm{C}_{\mathrm{q}}\right), 150.5\left(\mathrm{C}_{\mathrm{q}}\right), 134.6,132.0$, 114.0, 111.8, 109.6 $\left(\mathrm{C}_{\mathrm{q}}\right), 51.5,50.6,33.0,26.0,24.8$.

HR-MS (GC-EI): $m / z[M]^{+}$calcd for $\mathrm{C}_{14} \mathrm{H}_{19} \mathrm{NO}_{2}$ : 233.1416; found: 233.1424 .

\section{$N$-Cyclohexyl-2-methoxyaniline (5)}

Prepared according to general procedure A from 2-methoxyaniline $(114 \mu \mathrm{L}, 1.00 \mathrm{mmol}) ; 21 \mathrm{~h}$ reaction time; purified by column chromatography (cyclohexane-EtOAc, $40: 1$, size: $11 \times 2.8 \mathrm{~cm}$ ); yield: $166 \mathrm{mg}$ ( $810 \mu \mathrm{mol}, 81 \%$ ); amorphous, colorless solid.

Prepared according to general procedure B from 2-methoxyaniline ( $34.2 \mu \mathrm{L}, 300 \mu \mathrm{mol}$ ); 15 min reaction time; purified by column chromatography (cyclohexane-EtOAc, 100:1, size: $14 \times 0.8 \mathrm{~cm}$ ); yield: $52.6 \mathrm{mg}$ ( $256 \mu \mathrm{mol}, 85 \%)$; amorphous, colorless solid.

Prepared according to general procedure $C$ from 2-methoxyaniline $(114 \mu \mathrm{L}, 1.00 \mathrm{mmol}) ; 15 \mathrm{~min}$ reaction time; purified by column chromatography (cyclohexane-EtOAc, 100:1, 50:1, size: $20 \times 1.4 \mathrm{~cm}$ ); yield: $184 \mathrm{mg}$ (902 $\mu \mathrm{mol}, 90 \%)$; amorphous, colorless solid; mp $32{ }^{\circ} \mathrm{C}$; $R_{f}=0.31$ (cyclohexane-EtOAc, 3:1) (254 nm, $366 \mathrm{~nm}$, CAM: purple).

IR (ATR): 3422, 2919, 2849, 1600, 1507, 1449, 1252, 1234, 1219, 1125 , $1026,738 \mathrm{~cm}^{-1}$.

${ }^{1} \mathrm{H} \mathrm{NMR}\left(300 \mathrm{MHz}, \mathrm{CDCl}_{3}\right): \delta=6.87\left(\mathrm{td},{ }^{3} J_{\mathrm{HH}}=7.8 \mathrm{~Hz},{ }^{4} J_{\mathrm{HH}}=1.3 \mathrm{~Hz}, 1 \mathrm{H}\right.$, ArH), $6.78\left(\mathrm{dd},{ }^{3} J_{\mathrm{HH}}=8.1 \mathrm{~Hz},{ }^{4} J_{\mathrm{HH}}=1.0 \mathrm{~Hz}, 1 \mathrm{H}, \mathrm{ArH}\right), 6.70-6.58(\mathrm{~m}, 2 \mathrm{H}$, $2 \times \mathrm{ArH}), 4.16(\mathrm{~s}, 1 \mathrm{H}, \mathrm{NH}), 3.86\left(\mathrm{~s}, 3 \mathrm{H}, \mathrm{CH}_{3}\right), 3.35-3.20(\mathrm{~m}, 1 \mathrm{H}, \mathrm{CH})$, 2.17-2.00 (m, $\left.2 \mathrm{H}, \mathrm{CH}_{2}\right), 1.87-1.60\left(\mathrm{~m}, 3 \mathrm{H}, \mathrm{CH}_{2}\right), 1.50-1.12(\mathrm{~m}, 5 \mathrm{H}$, $\mathrm{CH}_{2}$ ).

${ }^{13} \mathrm{C} \operatorname{NMR}\left(75.53 \mathrm{MHz}, \mathrm{CDCl}_{3}\right): \delta=146.8\left(\mathrm{C}_{\mathrm{q}}\right), 137.4\left(\mathrm{C}_{\mathrm{q}}\right), 121.4,115.9$, $110.3,109.7,55.5,51.5,33.6,26.1,25.2$.

HR-MS (GC-EI): $m / z[M]^{+}$calcd for $\mathrm{C}_{13} \mathrm{H}_{19} \mathrm{NO}$ : 205.1467; found: 205.1471.

\section{N-Cyclohexyl-2,6-diisopropylaniline (6)}

Prepared according to general procedure B from 2,6-diisopropylaniline $(62.9 \mu \mathrm{L}, 300 \mu \mathrm{mol})$ using TMSOTf $(139 \mu \mathrm{L}, 750 \mu \mathrm{mol})$ instead of TMSCl; 230 min reaction time; purified by column chromatography (cyclohexane-EtOAc, 100:1, size: $8 \times 0.8 \mathrm{~cm}$ ); yield: $51.6 \mathrm{mg}(199$ $\mu \mathrm{mol}, 66 \%$ ); colorless, viscous liquid; $R_{f}=0.76$ (cyclohexane-EtOAc, 9:1) (254 nm, $\mathrm{KMnO}_{4}$ : yellow).

The spectra (see SI) were in accordance with the previously reported data. $^{32}$

\section{$N$-Cyclohexylaniline (7)}

Prepared according to general procedure A from aniline $(92.0 \mu \mathrm{L}, 1.00$ mmol); 19 h reaction time; purified by column chromatography (cyclohexane-EtOAc, 45:1, size: $11 \times 2.8 \mathrm{~cm})$; yield: $134 \mathrm{mg}(765 \mu \mathrm{mol}$, 77\%); light-yellow, viscous liquid. 
Prepared according to general procedure B from aniline $(27.7 \mu \mathrm{L}, 300$ $\mu \mathrm{mol}) ; 15$ min reaction time; purified by column chromatography (cyclohexane-EtOAc, 150:1, 80:1, size: $14 \times 0.8 \mathrm{~cm}$ ); yield: $40.4 \mathrm{mg}$ (230 $\mu \mathrm{mol}, 77 \%$ ); light-yellow, viscous liquid.

Prepared according to general procedure $\mathrm{C}$ from aniline $(92.0 \mu \mathrm{L}, 1.00$ $\mathrm{mmol}$ ); 15 min reaction time; purified by column chromatography (cyclohexane-EtOAc, 45:1, size: $15.5 \times 3.5 \mathrm{~cm})$; yield: $123 \mathrm{mg}(702$ $\mu \mathrm{mol}, 70 \%)$; light-yellow, viscous liquid.

$R_{f}=0.79$ (cyclohexane-EtOAc, 3:1) (254 nm, CAM: carnate).

The spectra (see SI) were in accordance with the previously reported data. $^{33}$

\section{Diethyl [2-(Cyclohexylamino)phenyl]phosphonate (8)}

Prepared according to general procedure A from diethyl (2-aminophenyl)phosphonate ${ }^{34}(229 \mathrm{mg}, 1.00 \mathrm{mmol})$; $3 \mathrm{~h}$ reaction time; purified by column chromatography (cyclohexane-EtOAc, 5:1, size: $11 \times$ $2.8 \mathrm{~cm}$ ); yield: $276 \mathrm{mg}$ ( $886 \mu \mathrm{mol}, 89 \%)$; light-yellow, viscous liquid.

Prepared according to general procedure B from diethyl (2-aminophenyl)phosphonate ${ }^{34}(68.8 \mathrm{mg}, 300 \mu \mathrm{mol}) ; 10$ min reaction time; purified by column chromatography (cyclohexane-EtOAc, 5:1, size: $15 \times 0.8 \mathrm{~cm})$; yield: $67.6 \mathrm{mg}(217 \mu \mathrm{mol}, 72 \%)$; light-yellow, viscous liquid.

$R_{f}=0.24$ (cyclohexane-EtOAc, 5:1) (254 nm, $366 \mathrm{~nm}$, CAM: blue).

IR (ATR): 3314, 2981, 2853, 1598, 1582, 1523, 1456, 1325, 1220, 1046 , $1017,955,747,559,532,513 \mathrm{~cm}^{-1}$.

${ }^{1} \mathrm{H}$ NMR (300 MHz, $\left.\mathrm{CDCl}_{3}\right): \delta=7.51-7.38(\mathrm{~m}, 1 \mathrm{H}, \mathrm{ArH}), 7.36-7.24(\mathrm{~m}$, $1 \mathrm{H}, \mathrm{ArH}), 6.69-6.44(\mathrm{~m}, 3 \mathrm{H}, 2 \times \mathrm{ArH}, \mathrm{NH}), 4.20-3.94\left(\mathrm{~m}, 4 \mathrm{H}, 2 \times \mathrm{CH}_{2}\right)$, 3.40-3.25 (m, $1 \mathrm{H}, \mathrm{CH}), 2.05-1.92\left(\mathrm{~m}, 2 \mathrm{H}, \mathrm{CH}_{2}\right), 1.84-1.68(\mathrm{~m}, 2 \mathrm{H}$, $\left.\mathrm{CH}_{2}\right), 1.65-1.53\left(\mathrm{~m}, 1 \mathrm{H}, \mathrm{CH}_{2}\right), 1.47-1.19\left(\mathrm{~m}, 11 \mathrm{H}, \mathrm{CH}_{2}, 2 \times \mathrm{CH}_{3}\right)$.

${ }^{13} \mathrm{C}$ NMR (75.53 MHz, $\left.\mathrm{CDCl}_{3}\right): \delta=151.2\left(\mathrm{~d},{ }^{2} J_{\mathrm{CP}}=9.0 \mathrm{~Hz}, \mathrm{C}_{\mathrm{q}}, \mathrm{Ar}-\mathrm{N}\right)$, $134.2\left(\mathrm{~d},{ }^{4} J_{\mathrm{CP}}=2.1 \mathrm{~Hz}, \mathrm{CH}_{\mathrm{arom}}\right), 134.0\left(\mathrm{~d},{ }^{2} J_{\mathrm{CP}}=7.3 \mathrm{~Hz}, \mathrm{CH}_{\text {arom }}\right), 114.8(\mathrm{~d}$, $\left.{ }^{3} J_{\mathrm{CP}}=14.2 \mathrm{~Hz}, \mathrm{CH}_{\mathrm{arom}}\right), 111.5\left(\mathrm{~d},{ }^{3} J_{\mathrm{CP}}=12.2 \mathrm{~Hz}, \mathrm{CH}_{\mathrm{arom}}\right), 107.5\left(\mathrm{~d},{ }^{1} J_{\mathrm{CP}}=\right.$ $182.6 \mathrm{~Hz}, \mathrm{C}, \mathrm{Ar}-\mathrm{P}), 62.0\left(\mathrm{~d},{ }^{2} J_{\mathrm{CP}}=4.9 \mathrm{~Hz}, \mathrm{CH}_{2}\right), 50.8(\mathrm{~s}, \mathrm{CH}), 32.8(\mathrm{~s}$, $\left.\mathrm{CH}_{2}\right), 26.0\left(\mathrm{~s}, \mathrm{CH}_{2}\right), 24.7\left(\mathrm{~s}, \mathrm{CH}_{2}\right), 16.4\left(\mathrm{~d},{ }^{3} \mathrm{JP}_{\mathrm{CP}}=6.7 \mathrm{~Hz}, \mathrm{CH}_{3}\right)$.

${ }^{31} \mathrm{P}$ NMR (122 MHz, $\left.\mathrm{CDCl}_{3}\right): \delta=22.06(\mathrm{~s})$.

HR-MS (GC-EI): $m / z$ [M] $]^{+}$calcd for $\mathrm{C}_{16} \mathrm{H}_{26} \mathrm{NO}_{3} \mathrm{P}: 311.1650$; found: 311.1669 .

\section{2,6-Dichloro- $N$-cyclohexylaniline (9)}

Prepared according to general procedure B from 2,6-dichloroaniline (49.6 mg, $300 \mu \mathrm{mol})$ and cyclohexanone ( $47.2 \mu \mathrm{L}, 450 \mu \mathrm{mol}) ; 18 \mathrm{~min}$ reaction time; purified by column chromatography (cyclohexaneEtOAc, $400: 1$, size: $14 \times 0.8 \mathrm{~cm}$ ); yield: $66.0 \mathrm{mg}(270 \mu \mathrm{mol}, 90 \%)$; colorless, viscous liquid.

Prepared according to general procedure $C$ from 2,6-dichloroaniline ( $165 \mathrm{mg}, 1.00 \mathrm{mmol}$ ); $15 \mathrm{~min}$ reaction time; purified by column chromatography (cyclohexane-EtOAc, 300:1, 150:1, size: $8 \times 2.7 \mathrm{~cm}$ ); yield: $213 \mathrm{mg}$ ( $872 \mu \mathrm{mol}, 87 \%)$; light-yellow, viscous liquid.

$R_{f}=0.84$ (cyclohexane-EtOAc, 9:1) (254 nm)

IR (ATR): 3355, 2926, 2851, 1580, 1493, 1447, 1421, 1249, 1139, 1081 , $889,836,805,762,723,623,528 \mathrm{~cm}^{-1}$.

${ }^{1} \mathrm{H} \mathrm{NMR}\left(300 \mathrm{MHz}, \mathrm{CDCl}_{3}\right): \delta=7.22\left(\mathrm{~d},{ }^{3} \mathrm{~J}_{\mathrm{HH}}=8.0 \mathrm{~Hz}, 2 \mathrm{H}, \mathrm{ArH}\right), 6.75(\mathrm{t}$, $\left.{ }^{3} J_{\mathrm{HH}}=8.0 \mathrm{~Hz}, 1 \mathrm{H}, \mathrm{ArH}\right), 3.98-3.37(\mathrm{~m}, 2 \mathrm{H}, \mathrm{NH}, \mathrm{CH}), 2.03-1.88(\mathrm{~m}, 2 \mathrm{H}$, $\left.\mathrm{CH}_{2}\right), 1.82-1.68\left(\mathrm{~m}, 2 \mathrm{H}, \mathrm{CH}_{2}\right), 1.67-1.53\left(\mathrm{~m}, 1 \mathrm{H}, \mathrm{CH}_{2}\right), 1.40-1.08(\mathrm{~m}, 5$ $\mathrm{H}, \mathrm{CH}_{2}$ ).

${ }^{13} \mathrm{C}$ NMR $\left(75.53 \mathrm{MHz}, \mathrm{CDCl}_{3}\right): \delta=142.1\left(\mathrm{C}_{\mathrm{q}}\right), 128.8,126.7\left(\mathrm{C}_{\mathrm{q}}\right), 121.5$, $55.4,34.5,25.9,25.2$.
HR-MS (GC-EI): $m / z$ [M] $]^{+}$calcd for $\mathrm{C}_{12} \mathrm{H}_{15} \mathrm{Cl}_{2} \mathrm{~N}$ : 243.0582; found: 243.0582 .

\section{2-(Cyclohexylamino)benzoic Acid (10)}

Prepared according to general procedure B from anthranilic acid (42.0 $\mathrm{mg}, 300 \mu \mathrm{mol}$ ); $10 \mathrm{~min}$ reaction time; purified by column chromatography (cyclohexane-EtOAc-AcOH, 100:10:1, size: $15 \times 0.8 \mathrm{~cm}$ ); yield: $59.9 \mathrm{mg}(273 \mu \mathrm{mol}, 91 \%)$; light-yellow solid.

Prepared according to general procedure $C$ from anthranilic acid (140 $\mathrm{mg}, 1.00 \mathrm{mmol}$ ); $15 \mathrm{~min}$ reaction time; purified by column chromatography (cyclohexane-EtOAc-AcOH, 100:10:1, size: $15 \times 3.5 \mathrm{~cm}$ ); yield: $200 \mathrm{mg}$ (912 $\mu \mathrm{mol}, 91 \%)$; light-yellow solid.

Mp $116{ }^{\circ} \mathrm{C}, R_{f}=0.18$ (cyclohexane-EtOAc-AcOH, 100:10:1) (254 nm, $366 \mathrm{~nm}$, CAM: orange-green).

The spectra (see SI) were in accordance with the previously reported data. $^{35}$

\section{1-[4-(Cyclohexylamino)phenyl]ethan-1-one (11)}

Prepared according to general procedure A from 4-aminoacetophenone $(138 \mathrm{mg}, 1.00 \mathrm{mmol}) ; 21 \mathrm{~h}$ reaction time, purified by column chromatography (cyclohexane-EtOAc, 40:1, size: $13 \times 2.8 \mathrm{~cm}$ ), yield: $62.5 \mathrm{mg}$ (288 $\mu \mathrm{mol}, 29 \%) ;$ light-orange, sticky solid.

Prepared according to general procedure B from 4-aminoacetophenone ( $41.4 \mathrm{mg}, 300 \mu \mathrm{mol}) ; 15 \mathrm{~min}$ reaction time; purified by column chromatography (cyclohexane-EtOAc, 9:1, size: $15 \times 0.8 \mathrm{~cm}$ ), yield: $51.5 \mathrm{mg}(237 \mu \mathrm{mol}, 79 \%)$; light-yellow solid.

Mp $115-117^{\circ} \mathrm{C} ; R_{f}=0.43$ (cyclohexane-EtOAc, 3:1) (254 nm).

IR (ATR): 3324, 2924, 2914, 2852, 1648, 1584, 1569, 1451, 1431, 1359 , 1339, 1279, 1257, 1170, 1147, 1106, 1069, 953, 823, 611, 568, 498, $468 \mathrm{~cm}^{-1}$.

${ }^{1} \mathrm{H} \mathrm{NMR}\left(300 \mathrm{MHz}, \mathrm{CDCl}_{3}\right): \delta=7.79\left(\mathrm{~d},{ }^{3} \mathrm{~J}_{\mathrm{HH}}=8.7 \mathrm{~Hz}, 2 \mathrm{H}, \mathrm{ArH}\right), 6.52(\mathrm{~d}$, $\left.{ }^{3} J_{\mathrm{HH}}=8.7 \mathrm{~Hz}, 2 \mathrm{H}, \mathrm{ArH}\right), 4.47-3.85(\mathrm{~m}, 1 \mathrm{H}, \mathrm{NH}), 3.42-3.24(\mathrm{~m}, 1 \mathrm{H}, \mathrm{CH})$, $2.48\left(\mathrm{~s}, 3 \mathrm{H}, \mathrm{CH}_{3}\right), 2.12-1.96\left(\mathrm{~m}, 2 \mathrm{H}, \mathrm{CH}_{2}\right), 1.86-1.58\left(\mathrm{~m}, 3 \mathrm{H}, \mathrm{CH}_{2}\right)$, 1.49-1.07 (m, $\left.5 \mathrm{H}, \mathrm{CH}_{2}\right)$.

${ }^{13} \mathrm{C}$ NMR $\left(75.53 \mathrm{MHz}, \mathrm{CDCl}_{3}\right): \delta=196.3\left(\mathrm{C}_{\mathrm{q}}\right), 151.5\left(\mathrm{C}_{\mathrm{q}}\right), 131.0,126.3$ $\left(\mathrm{C}_{\mathrm{q}}\right), 111.6,51.4,33.2,26.0,25.8,24.9$.

HR-MS (GC-EI): $m / z$ [M] $]^{+}$calcd for $\mathrm{C}_{14} \mathrm{H}_{19} \mathrm{NO}$ : 217.1467; found: 217.1470.

\section{N-Cyclohexyl-2-fluoro-5-(trifluoromethyl)aniline (12)}

Prepared according to general procedure A from 2-fluoro-5-(trifluoromethyl)aniline $(134 \mu \mathrm{L}, 1.00 \mathrm{mmol}) ; 3 \mathrm{~h}$ reaction time; purified by column chromatography (cyclohexane, size: $9.5 \times 3.6 \mathrm{~cm}$ ); yield: 187 mg $(717 \mu \mathrm{mol}, 72 \%)$; colorless, viscous liquid.

Prepared according to general procedure B from 2-fluoro-5-(trifluoromethyl)aniline $(40.2 \mu \mathrm{L}, 300 \mu \mathrm{mol}) ; 10 \mathrm{~min}$ reaction time; purified by column chromatography (cyclohexane-EtOAc, 300:1, size: $15 \times 0.8$ $\mathrm{cm}$ ); yield: $53.2 \mathrm{mg}$ (204 $\mu \mathrm{mol}, 68 \%)$; colorless, viscous liquid.

Prepared according to general procedure $C$ from 2-fluoro-5-(trifluoromethyl)aniline ( $134 \mu \mathrm{L}, 1.00 \mathrm{mmol}) ; 15 \mathrm{~min}$ reaction time; purified by column chromatography (cyclohexane, size: $15.5 \times 3.0 \mathrm{~cm}$ ); yield: $174 \mathrm{mg}$ (666 $\mu \mathrm{mol}, 67 \%)$; light-yellow, viscous liquid.

$R_{f}=0.85$ (cyclohexane-EtOAc, 3:1) (254 nm, $\mathrm{KMnO}_{4}$ : yellow).

IR (ATR): 3435, 2932, 2857, 1624, 1534, 1444, 1351, 1322, 1302, 1283 , 1259, 1240, 1195, 1161, 1091, 1066, 934, 853, 805, 658, 625, $610 \mathrm{~cm}^{-1}$. 
${ }^{1} \mathrm{H}$ NMR $\left(300 \mathrm{MHz}, \mathrm{CDCl}_{3}\right): \delta=7.07-6.94(\mathrm{~m}, 1 \mathrm{H}, \mathrm{ArH}), 6.91-6.78(\mathrm{~m}$, $2 \mathrm{H}, \mathrm{ArH}), 3.95$ (br s, $1 \mathrm{H}, \mathrm{NH}), 3.41-3.19(\mathrm{~m}, 1 \mathrm{H}, \mathrm{CH}), 2.13-1.93(\mathrm{~m}, 2$ $\left.\mathrm{H}, \mathrm{CH}_{2}\right), 1.87-1.57\left(\mathrm{~m}, 3 \mathrm{H}, \mathrm{CH}_{2}\right), 1.51-1.10\left(\mathrm{~m}, 6 \mathrm{H}, \mathrm{CH}_{2}\right)$.

${ }^{13} \mathrm{C}$ NMR (75.53 MHz, $\left.\mathrm{CDCl}_{3}\right): \delta=153.0\left(\mathrm{~d},{ }^{1} J_{\mathrm{CF}}=243.1 \mathrm{~Hz}, \mathrm{C}_{\mathrm{q}}, \mathrm{Ar}-\mathrm{F}\right)$, $136.4\left(\mathrm{~d},{ }^{2} J_{\mathrm{CF}}=12.3 \mathrm{~Hz}, \mathrm{C}_{\mathrm{q}}, \mathrm{Ar}-\mathrm{N}\right), 127.3\left(\mathrm{dd},{ }^{2} J_{\mathrm{CF}}=32.1 \mathrm{~Hz},{ }^{4} J_{\mathrm{CF}}=3.2 \mathrm{~Hz}\right.$, $\left.\mathrm{C}_{\mathrm{q}}, \mathrm{Ar}-\mathrm{CF}_{3}\right), 124.4\left(\mathrm{~d},{ }^{1} J_{\mathrm{CF}}=271.9 \mathrm{~Hz}, \mathrm{CF}_{3}\right), 114.7\left(\mathrm{~d},{ }^{2} J_{\mathrm{CF}}=20.3 \mathrm{~Hz}\right.$, $\mathrm{CH}_{\text {arom }}$ ), 113.3-112.7 (m, $\left.\mathrm{CH}_{\text {arom }}\right), 109.0-108.7\left(\mathrm{~m}, \mathrm{CH}_{\text {arom }}\right), 51.4(\mathrm{~s}$, $\mathrm{CH}), 33.3,25.9,25.0$.

${ }^{19} \mathrm{~F}$ NMR $\left(282 \mathrm{MHz}, \mathrm{CDCl}_{3}\right): \delta=-62.07,-132.19$.

HR-MS (GC-EI): $m / z$ [M] $]^{+}$calcd for $\mathrm{C}_{13} \mathrm{H}_{15} \mathrm{~F}_{4} \mathrm{~N}$ : 261.1141; found: 261.1145 .

\section{2-(Cyclohexylamino)benzonitrile (13)}

Prepared according to general procedure A from 2-aminobenzonitrile (121 mg, $1.00 \mathrm{mmol}$ ); $15 \mathrm{~h}$ reaction time; purified by column chromatography (cyclohexane-EtOAc, 50:1, size: $11 \times 2.6 \mathrm{~cm}$ ); yield: 188 mg (938 $\mu \mathrm{mol}$, 94\%); colorless solid.

Prepared according to general procedure B from 2-aminobenzonitrile (36.2 $\mathrm{mg}, 300 \mu \mathrm{mol}$ ); $18 \mathrm{~min}$ reaction time; purified by column chromatography (cyclohexane-EtOAc, 100:1, size: $16 \times 0.8 \mathrm{~cm}$ ); yield: $56.2 \mathrm{mg}(281 \mu \mathrm{mol}, 94 \%)$; colorless solid.

Prepared according to general procedure $\mathrm{C}$ from 2-aminobenzonitrile (121 mg, $1.00 \mathrm{mmol}$ ); $15 \mathrm{~min}$ reaction time; purified by column chromatography (cyclohexane-EtOAc, 70:1, size: $7 \times 2.7 \mathrm{~cm}$ ); yield: 182 $\mathrm{mg}(910 \mu \mathrm{mol}, 91 \%)$; light-yellow solid.

Mp 61-62 ${ }^{\circ} \mathrm{C} ; R_{f}=0.32$ (cyclohexane-EtOAc, 30:1) $(254 \mathrm{~nm}, 366 \mathrm{~nm}$, CAM: orange).

The spectra (see SI) were in accordance with the previously reported data. ${ }^{36}$

\section{$\mathrm{N}$-Cyclohexyl-2-nitroaniline (14)}

Prepared according to general procedure A from 2-nitroaniline (141 $\mathrm{mg}, 1.00 \mathrm{mmol}) ; 21 \mathrm{~h}$ reaction time; purified by column chromatography (cyclohexane-EtOAc, 50:1, size: $11 \times 2.8 \mathrm{~cm}$ ); yield: $162 \mathrm{mg}$ (735 $\mu \mathrm{mol}, 74 \%$ ); bright-orange solid.

Prepared according to general procedure B from 2-nitroaniline (42.3 $\mathrm{mg}, 300 \mu \mathrm{mol}) ; 30 \mathrm{~min}$ reaction time; purified by column chromatography (cyclohexane-EtOAc, $80: 1$, size: $7.5 \times 2.2 \mathrm{~cm}$ ); yield: $62.1 \mathrm{mg}$ (282 $\mu \mathrm{mol}, 94 \%$ ); bright-orange solid.

Prepared according to general procedure $C$ from 2-nitroaniline (42.3 $\mathrm{mg}, 300 \mu \mathrm{mol}$ ); 30 min reaction time; purified by column chromatography (cyclohexane-EtOAc, 80:1, size: $7.5 \times 2.2 \mathrm{~cm}$ ); yield: $51.5 \mathrm{mg}$ (234 $\mu \mathrm{mol}, 78 \%$ ); bright-orange solid.

Mp 101-103 ${ }^{\circ} \mathrm{C}, R_{f}=0.70$ (cyclohexane-EtOAc, 2:1) (254 nm, VIS: orange).

The spectra (see SI) were in accordance with the previously reported data. ${ }^{37}$

\section{$\mathbf{N}$-Cyclohexylpyridin-3-amine (15)}

Prepared according to general procedure B from 3-aminopyridine ( $28.5 \mathrm{mg}, 300 \mu \mathrm{mol}$ ); $11 \mathrm{~min}$ reaction time; purified by column chromatography $\left(\mathrm{CH}_{2} \mathrm{Cl}_{2}-\mathrm{MeOH}, 80: 1\right.$, size: $\left.13 \times 1 \mathrm{~cm}\right)$; yield: $44.2 \mathrm{mg}$ (251 $\mu$ mol, 84\%); light-beige solid; $\mathrm{mp} 86-89{ }^{\circ} \mathrm{C} ; R_{f}=0.20\left(\mathrm{CH}_{2} \mathrm{Cl}_{2}-\right.$ $\mathrm{MeOH}, 80: 1$ ) (254 nm, $366 \mathrm{~nm}, \mathrm{KMnO}_{4}$ : yellow).

The spectra (see $\mathrm{SI}$ ) were in accordance with the previously reported data. ${ }^{38}$

\section{2-(Benzylamino)benzonitrile (16)}

Prepared according to general procedure A from 2-aminobenzonitrile (121 mg, $1.00 \mathrm{mmol}$ ) and benzaldehyde ( $155 \mu \mathrm{L}, 1.5 \mathrm{mmol}) ; 15 \mathrm{~h}$ reaction time; purified by column chromatography (cyclohexane-EtOAc, 30:1, size: $11 \times 2.6 \mathrm{~cm}$ ); yield: $167 \mathrm{mg}(803 \mu \mathrm{mol}, 80 \%)$; colorless solid; $\mathrm{mp} 110-112^{\circ} \mathrm{C} ; R_{f}=0.15$ (cyclohexane-EtOAc, 30:1) (254 nm, 366 nm, CAM: violet-grey).

The spectra (see SI) were in accordance with the previously reported data. $^{39}$

\section{Methyl 2-(Benzylamino)benzoate (17)}

Prepared according to general procedure B from methyl anthranilate (39.2 $\mu \mathrm{L}, 300 \mu \mathrm{mol})$ and benzaldehyde ( $33.9 \mu \mathrm{L}, 330 \mu \mathrm{mol}) ; 20 \mathrm{~min}$ reaction time; purified by column chromatography (cyclohexaneEtOAc, 100:1, 70:1, size: $12 \times 2.4 \mathrm{~cm})$; yield: $61.6 \mathrm{mg}(255 \mu \mathrm{mol}, 85 \%)$; light-yellow, very viscous liquid; $R_{f}=0.72$ (cyclohexane-EtOAc, 4:1) (254 nm, $366 \mathrm{~nm})$.

IR (ATR): 3380, 2945, 1672, 1601, 1576, 1516, 1494, 1453, 1434, 1323 , 1287, 1225, 1187, 1166, 1147, 1102, 1077, 753, 728, 703, 693, 595, $566,527,458 \mathrm{~cm}^{-1}$.

${ }^{1} \mathrm{H} \mathrm{NMR}\left(300 \mathrm{MHz}, \mathrm{CDCl}_{3}\right): \delta=8.09(\mathrm{br} \mathrm{s}, 1 \mathrm{H}, \mathrm{NH}), 7.84\left(\mathrm{dd},{ }^{3} J_{\mathrm{HH}}=8.0\right.$ $\left.\mathrm{Hz},{ }^{4} \mathrm{JHH}_{\mathrm{HH}}=1.3 \mathrm{~Hz}, 1 \mathrm{H}, \mathrm{ArH}\right), 7.36-7.12(\mathrm{~m}, 6 \mathrm{H}, \mathrm{ArH}), 6.63-6.45(\mathrm{~m}, 2$ $\mathrm{H}, \mathrm{ArH}), 4.37$ (s, $\left.2 \mathrm{H}, \mathrm{CH}_{2}\right), 3.78\left(\mathrm{~s}, 3 \mathrm{H}, \mathrm{CH}_{3}\right)$.

${ }^{13} \mathrm{C}$ NMR $\left(75.53 \mathrm{MHz}, \mathrm{CDCl}_{3}\right): \delta=169.2\left(\mathrm{C}_{\mathrm{q}}\right), 151.1\left(\mathrm{C}_{\mathrm{q}}\right), 139.0\left(\mathrm{C}_{\mathrm{q}}\right)$, 134.7, 131.8, 128.8, 127.3, 127.2, 115.0, 111.8, 110.4 ( $\left.\mathrm{C}_{\mathrm{q}}\right)$, 51.6, 47.2.

HR-MS (GC-EI): $m / z[M]^{+}$calcd for $\mathrm{C}_{15} \mathrm{H}_{15} \mathrm{NO}_{2}$ : 241.1103; found: 241.1108.

\section{Methyl 2-[(Pyridin-3-ylmethyl)amino]benzoate (18)}

Prepared according to general procedure B from methyl anthranilate $(39.2 \mu \mathrm{L}, 300 \mu \mathrm{mol})$ and 3-pyridinecarboxaldehyde $(31.6 \mu \mathrm{L}, 330$ $\mu \mathrm{mol}) ; 10$ min reaction time; purified by column chromatography (cyclohexane-EtOAc, 3:1, 2:1, size: $15 \times 0.8 \mathrm{~cm})$; yield: $61.1 \mathrm{mg}(252$ $\mu \mathrm{mol}, 84 \%$ ); light-yellow, viscous liquid; $\mathrm{Rf}=0.16$ (cyclohexane-EtOAc, 2:1) (254 nm, $366 \mathrm{~nm})$.

IR (ATR): 3473, 3365, 2950, 2846, 1680, 1607, 1586, 1516, 1487, 1452 , 1297, 1238, 1188, 1161, 1094, 1024, 962, 748, 699, 665, 526, $499 \mathrm{~cm}^{-1}$.

${ }^{1} \mathrm{H}$ NMR $\left(300 \mathrm{MHz}, \mathrm{CDCl}_{3}\right): \delta=8.70-8.62(\mathrm{~m}, 1 \mathrm{H}, \mathrm{ArH}), 8.55\left(\mathrm{~d},{ }^{3} J_{\mathrm{HH}}=\right.$ $3.9 \mathrm{~Hz}, 1 \mathrm{H}, \mathrm{ArH}), 8.23$ (br s, $1 \mathrm{H}, \mathrm{NH}), 7.96\left(\mathrm{dd},{ }^{3} J_{\mathrm{HH}}=8.0 \mathrm{~Hz},{ }^{4} J_{\mathrm{HH}}=1.2\right.$ $\mathrm{Hz}, 1 \mathrm{H}, \mathrm{ArH}), 7.70\left(\mathrm{~d},{ }^{3} \mathrm{HH}_{\mathrm{HH}}=7.8 \mathrm{~Hz}, 1 \mathrm{H}, \mathrm{ArH}\right), 7.39-7.23(\mathrm{~m}, 2 \mathrm{H}, \mathrm{ArH})$, 6.71-6.58 (m, $2 \mathrm{H}, \mathrm{ArH}), 4.50\left(\mathrm{~d},{ }^{3} \mathrm{HH}_{\mathrm{HH}}=5.5 \mathrm{~Hz}, 2 \mathrm{H}, \mathrm{CH}_{2}\right), 3.89(\mathrm{~s}, 3 \mathrm{H}$, $\mathrm{CH}_{3}$ ).

${ }^{13} \mathrm{C}$ NMR $\left(75.53 \mathrm{MHz}, \mathrm{CDCl}_{3}\right): \delta=169.2\left(\mathrm{C}_{\mathrm{q}}\right), 150.6\left(\mathrm{C}_{\mathrm{q}}\right), 149.1,148.8$, 134.9, 134.8, $134.5\left(\mathrm{C}_{\mathrm{q}}\right), 131.9,123.7,115.5,111.6,110.71\left(\mathrm{C}_{\mathrm{q}}\right), 51.7$, 44.7.

HR-MS (GC-EI): $m / z$ [M] $]^{+}$calcd for $\mathrm{C}_{14} \mathrm{H}_{14} \mathrm{~N}_{2} \mathrm{O}_{2}$ : 242.1055; found: 242.1058

\section{Methyl 2-(Cinnamylamino)benzoate (19)}

Prepared according to general procedure B from methyl anthranilate $(39.2 \mu \mathrm{L}, 300 \mu \mathrm{mol})$ and cinnamic aldehyde $(42.4 \mathrm{mg}, 330 \mu \mathrm{mol}) ; 10$ min reaction time; purified by column chromatography (cyclohexane-EtOAc, 50:1, size: $15 \times 0.8 \mathrm{~cm})$; yield: $65.0 \mathrm{mg}(243 \mu \mathrm{mol}, 81 \%)$; yellow-orange, amorphous solid; $\mathrm{mp} 33-35^{\circ} \mathrm{C} ; R_{f}=0.88$ (cyclohexane-EtOAc, 3:1) (254 nm, $366 \mathrm{~nm}$, CAM: yellow).

IR (ATR): 3386, 3362, 3023, 3003, 2947, 2844, 1675, 1605, 1575, 1513 , 1436, 1318, 1278, 1254, 1219, 1191, 1163, 1149, 1096, 1081, 1048, $963,743,730,691,664,528 \mathrm{~cm}^{-1}$. 
${ }^{1} \mathrm{H}$ NMR $\left(300 \mathrm{MHz}, \mathrm{CDCl}_{3}\right): \delta=8.10-7.75(\mathrm{~m}, 2 \mathrm{H}, \mathrm{NH}, \mathrm{ArH}), 7.41-7.14$ $(\mathrm{m}, 6 \mathrm{H}, \mathrm{ArH}), 6.71\left(\mathrm{~d},{ }^{3} J_{\mathrm{HH}}=8.5 \mathrm{~Hz}, 1 \mathrm{H}\right), 6.66-6.53(\mathrm{~m}, 2 \mathrm{H}), 6.37-$ $6.22(\mathrm{~m}, 1 \mathrm{H}), 4.05\left(\mathrm{~d},{ }^{3} \mathrm{HH}_{\mathrm{HH}}=11.5 \mathrm{~Hz}, 2 \mathrm{H}, \mathrm{CH}_{2}\right), 3.85\left(\mathrm{~s}, 3 \mathrm{H}, \mathrm{CH}_{3}\right)$.

${ }^{13} \mathrm{C}$ NMR $\left(75.53 \mathrm{MHz}, \mathrm{CDCl}_{3}\right): \delta=169.2\left(\mathrm{C}_{\mathrm{q}}\right), 151.1\left(\mathrm{C}_{\mathrm{q}}\right), 137.0\left(\mathrm{C}_{\mathrm{q}}\right)$, 134.7, 131.8, 131.6, 128.7, 127.6, 126.51, 126.47, 115.0, 111.8, 110.4 $\left(\mathrm{C}_{\mathrm{q}}\right), 51.6,45.1$.

HR-MS (GC-EI): $m / z[M]^{+}$calcd for $\mathrm{C}_{17} \mathrm{H}_{17} \mathrm{NO}_{2}$ : 267.1259; found: 267.1273 .

\section{Methyl 2-(Cyclopentylamino)benzoate (20)}

Prepared according to general procedure B from methyl anthranilate (39.2 $\mu \mathrm{L}, 300 \mu \mathrm{mol})$ and cyclopentanone $(29.5 \mu \mathrm{L}, 330 \mu \mathrm{mol}) ; 15 \mathrm{~min}$ reaction time; purified by column chromatography (cyclohexaneEtOAc, 250:1, size: $8 \times 0.8 \mathrm{~cm}$ ); yield: $63.0 \mathrm{mg}(287 \mu \mathrm{mol}, 96 \%)$; colorless liquid; $R_{f}=0.20$ (cyclohexane-EtOAc, 200:1) $(254 \mathrm{~nm}, 366 \mathrm{~nm}$, CAM: orange-green).

IR (ATR): 3353, 2950, 2869, 1680, 1606, 1579, 1514, 1457, 1435, 1331, 1256, 1231, 1184, 1161, 1138, 1086, 1077, 1046, 745, 702, $526 \mathrm{~cm}^{-1}$.

${ }^{1} \mathrm{H}$ NMR (300 MHz, CDCl $)$ : $\delta=7.98-7.65$ (m, $\left.2 \mathrm{H}, \mathrm{NH}, \mathrm{ArH}\right), 7.40-7.28$ $(\mathrm{m}, 1 \mathrm{H}, \mathrm{ArH}), 6.72\left(\mathrm{~d}, 3_{\mathrm{HH}}=8.5 \mathrm{~Hz}, 1 \mathrm{H}, \mathrm{ArH}\right), 6.55\left(\mathrm{t}, 3_{\mathrm{HH}}=7.5 \mathrm{~Hz}, 1\right.$ $\mathrm{H}, \mathrm{ArH}$ ), 3.95-3.75 (m, $\left.4 \mathrm{H}, \mathrm{CH}, \mathrm{CH}_{3}\right), 2.14-1.93\left(\mathrm{~m}, 2 \mathrm{H}, \mathrm{CH}_{2}\right), 1.88-$ $1.49\left(\mathrm{~m}, 6 \mathrm{H}, \mathrm{CH}_{2}\right)$.

${ }^{13} \mathrm{C} \operatorname{NMR}\left(75.53 \mathrm{MHz}, \mathrm{CDCl}_{3}\right): \delta=169.3\left(\mathrm{C}_{\mathrm{q}}\right), 150.9\left(\mathrm{C}_{\mathrm{q}}\right), 134.6,131.8$, 114.2, 112.2, $109.8\left(\mathrm{C}_{\mathrm{q}}\right), 53.8,51.5,33.6,24.2$.

HR-MS (GC-EI): $m / z[M]^{+}$calcd for $\mathrm{C}_{13} \mathrm{H}_{17} \mathrm{NO}_{2}$ : 219.1259; found: 219.1260 .

\section{Methyl 2-(Cycloheptylamino)benzoate (21)}

Prepared according to general procedure B from methyl anthranilate (39.2 $\mu \mathrm{L}, 300 \mu \mathrm{mol})$ and cycloheptanone (39.3 $\mu \mathrm{L}, 330 \mu \mathrm{mol}) ; 15 \mathrm{~min}$ reaction time; purified by column chromatography (cyclohexaneEtOAc, $200: 1$, size: $8 \times 0.8 \mathrm{~cm})$; yield: $67.5 \mathrm{mg}(273 \mu \mathrm{mol}, 91 \%)$; colorless, very viscous liquid; $R_{f}=0.23$ (cyclohexane-EtOAc, 200:1) (254 $\mathrm{nm}, 366 \mathrm{~nm}$, CAM: orange-green).

IR (ATR): 3349, 2923, 2853, 1681, 1606, 1579, 1515, 1457, 1436, 1328 , $1227,1187,1161,1142,1087,1046,841,745,702,569,525 \mathrm{~cm}^{-1}$.

${ }^{1} \mathrm{H} \mathrm{NMR}\left(300 \mathrm{MHz}, \mathrm{CDCl}_{3}\right): \delta=8.12-7.67(\mathrm{~m}, 2 \mathrm{H}, \mathrm{NH}, \mathrm{ArH}), 7.39-7.28$ (m, $1 \mathrm{H}, \mathrm{ArH}), 6.73-6.46(\mathrm{~m}, 2 \mathrm{H}, \mathrm{ArH}), 3.85\left(\mathrm{~s}, 3 \mathrm{H}, \mathrm{CH}_{3}\right), 3.66-3.47$ (m, $1 \mathrm{H}, \mathrm{CH}), 2.09-1.89\left(\mathrm{~m}, 2 \mathrm{H}, \mathrm{CH}_{2}\right), 1.78-1.43\left(\mathrm{~m}, 10 \mathrm{H}, \mathrm{CH}_{2}\right)$.

${ }^{13} \mathrm{C}$ NMR $\left(75.53 \mathrm{MHz}, \mathrm{CDCl}_{3}\right): \delta=169.3\left(\mathrm{C}_{\mathrm{q}}\right), 150.2\left(\mathrm{C}_{\mathrm{q}}\right), 134.6,132.0$, 114.1, 112.1, $109.9\left(C_{q}\right), 52.9,51.5,34.7,28.4,24.4$

HR-MS (GC-EI): $m / z[M]^{+}$calcd for $\mathrm{C}_{15} \mathrm{H}_{21} \mathrm{NO}_{2}$ : 247.1572; found: 247.1589.

\section{Ethyl 4-\{[2-(Methoxycarbonyl)phenyl]amino\}piperidine-1-car- boxylate (22)}

Prepared according to general procedure B from methyl anthranilate $(39.2 \mu \mathrm{L}, 300 \mu \mathrm{mol})$ and ethyl 4-oxopiperidine-1-carboxylate $(50.7 \mu \mathrm{L}$, $330 \mu \mathrm{mol}) ; 15 \mathrm{~min}$ reaction time; purified by column chromatography (cyclohexane-EtOAc, 7:1, 6:1, size: $6 \times 2.2 \mathrm{~cm}$ ); yield: $88.3 \mathrm{mg}$ (288 $\mu \mathrm{mol}, 96 \%$ ); light-yellow, viscous liquid; $R_{f}=0.30$ (cyclohexaneEtOAc, 3:1) (254 nm, 366 nm, CAM: orange-green).

IR (ATR): 3342, 2981, 2948, 2856, 1680, 1605, 1581, 1517, 1455, 1431 , 1379, 1330, 1238, 1220, 1192, 1155, 1128, 1096, 1075, 1032, 974, $848,747,703,559 \mathrm{~cm}^{-1}$.

${ }^{1} \mathrm{H}$ NMR (300 MHz, CDCl $)$ : $\delta=7.99-7.69(\mathrm{~m}, 2 \mathrm{H}, \mathrm{ArH}, \mathrm{NH}), 7.31(\mathrm{t}$, $\left.{ }^{3} J_{\mathrm{HH}}=7.8 \mathrm{~Hz}, 1 \mathrm{H}, \mathrm{ArH}\right), 6.67\left(\mathrm{~d},{ }^{3} J_{\mathrm{HH}}=8.5 \mathrm{~Hz}, 1 \mathrm{H}, \mathrm{ArH}\right), 6.56\left(\mathrm{t},{ }^{3} J_{\mathrm{HH}}=\right.$ $7.5 \mathrm{~Hz}, 1 \mathrm{H}, \mathrm{ArH}), 4.12\left(\mathrm{q},{ }^{3} \mathrm{HH}_{\mathrm{HH}}=7.0 \mathrm{~Hz}, 2 \mathrm{H}, \mathrm{CH}_{2}-\mathrm{O}\right), 4.04-3.87(\mathrm{~m}, 2 \mathrm{H}$,
$\left.\mathrm{CH}_{2}\right), 3.82\left(\mathrm{~s}, 3 \mathrm{H}, \mathrm{CH}_{3}\right), 3.65-3.49(\mathrm{~m}, 1 \mathrm{H}, \mathrm{CH}), 3.22-3.00(\mathrm{~m}, 2 \mathrm{H}$, $\left.\mathrm{CH}_{2}\right), 2.10-1.89\left(\mathrm{~m}, 2 \mathrm{H}, \mathrm{CH}_{2}\right), 1.62-1.39\left(\mathrm{~m}, 2 \mathrm{H}, \mathrm{CH}_{2}\right), 1.25\left(\mathrm{t}, 3_{\mathrm{HH}}=\right.$ $\left.7.0 \mathrm{~Hz}, 3 \mathrm{H}, \mathrm{CH}_{3}\right)$.

${ }^{13} \mathrm{C}$ NMR $\left(75.53 \mathrm{MHz}, \mathrm{CDCl}_{3}\right): \delta=169.1\left(\mathrm{C}_{\mathrm{q}}\right), 155.6\left(\mathrm{C}_{\mathrm{q}}\right), 149.9\left(\mathrm{C}_{\mathrm{q}}\right)$, 134.6, 132.0, 114.7, 111.5, $110.1\left(\mathrm{C}_{\mathrm{q}}\right), 61.4,51.5,48.5,42.2,31.7,14.7$. HR-MS: $m / z[M]^{+}$calcd for $\mathrm{C}_{16} \mathrm{H}_{22} \mathrm{~N}_{2} \mathrm{O}_{4}$ : 306.1580; found: 306.1595 .

tert-Butyl 3-\{[2-(Methoxycarbonyl)phenyl]amino\}piperidine-1carboxylate (23)

Prepared according to general procedure A from methyl anthranilate $(131 \mu \mathrm{L}, 1.00 \mathrm{mmol}$ ) and 1-Boc-3-piperidone (305 mg, $1.50 \mathrm{mmol}$ ); 44 h reaction time; purified by column chromatography (cyclohexane-EtOAc, $20: 1$, size: $20 \times 1.2 \mathrm{~cm}$ ); yield: $220 \mathrm{mg}(657 \mu \mathrm{mol}, 66 \%$; light-yellow, very viscous liquid; $R_{f}=0.49$ (cyclohexane-EtOAc, 3:1) (254 nm, $366 \mathrm{~nm}$, CAM: crimson).

IR (ATR): 3342, 2974, 2935, 2857, 1681, 1606, 1581, 1517, 1457, 1421, $1365,1331,1255,1237,1141,1076,973,867,747,704,526 \mathrm{~cm}^{-1}$.

${ }^{1} \mathrm{H}$ NMR $\left(300 \mathrm{MHz}, \mathrm{CDCl}_{3}\right.$ ): $\delta=7.97-7.70(\mathrm{~m}, 2 \mathrm{H}, \mathrm{NH}, \mathrm{ArH}), 7.34(\mathrm{dd}$, $\left.{ }^{3} J_{\mathrm{HH}}=11.3 \mathrm{~Hz},{ }^{4} J_{\mathrm{HH}}=4.2 \mathrm{~Hz}, 1 \mathrm{H}, \mathrm{ArH}\right), 6.80\left(\mathrm{~d},{ }^{3} J_{\mathrm{HH}}=8.2 \mathrm{~Hz}, 1 \mathrm{H}, \mathrm{ArH}\right)$, $6.59\left(\mathrm{t},{ }^{3} J_{\mathrm{HH}}=7.5 \mathrm{~Hz}, 1 \mathrm{H}, \mathrm{ArH}\right), 4.41-3.61\left(\mathrm{~m}, 5 \mathrm{H}, \mathrm{CH}_{3}, \mathrm{CH}_{2}\right), 3.54-$ $3.37(\mathrm{~m}, 1 \mathrm{H}, \mathrm{CH}), 3.26-2.56\left(\mathrm{~m}, 2 \mathrm{H}, \mathrm{CH}_{2}\right), 2.18-1.95\left(\mathrm{~m}, 1 \mathrm{H}, \mathrm{CH}_{2}\right)$, 1.89-1.27 (m, $\left.12 \mathrm{H}, \mathrm{CH}_{2}, 3 \times \mathrm{CH}_{3}\right)$.

${ }^{13} \mathrm{C}$ NMR $\left(75.53 \mathrm{MHz}, \mathrm{CDCl}_{3}\right): \delta=169.2\left(\mathrm{C}_{\mathrm{q}}\right), 154.8\left(\mathrm{C}_{\mathrm{q}}\right), 150.0\left(\mathrm{C}_{\mathrm{q}}\right)$, 134.8, 131.9, 115.0, 111.8, $110.3\left(\mathrm{C}_{\mathrm{q}}\right), 79.7\left(\mathrm{C}_{\mathrm{q}}\right)$, 51.6, 48.8, 48.4, 44.1, 31.0, 28.5, 23.8 .

HR-MS (DI-EI): $m / z$ [M] $]^{+}$calcd for $\mathrm{C}_{18} \mathrm{H}_{26} \mathrm{~N}_{2} \mathrm{O}_{4}$ : 334.1893; found 334.1894.

\section{2-(Adamantan-2-ylamino)benzonitrile (24)}

Prepared according to general procedure A from 2-aminobenzonitrile (121 mg, $1.00 \mathrm{mmol}$ ) and 2-adamantanone (228 mg, $1.50 \mathrm{mmol}$ ); 41 $\mathrm{h}$ reaction time; purified by column chromatography (cyclohexaneEtOAc, 50:1, size: $12 \times 2.7 \mathrm{~cm}$ ); yield: $203 \mathrm{mg}(803 \mu \mathrm{mol}, 80 \%)$; colorless solid; mp $96-100{ }^{\circ} \mathrm{C} ; R_{f}=0.30$ (cyclohexane-EtOAc, 50:1) (254 $\mathrm{nm}, 366 \mathrm{~nm}, \mathrm{CAM}$ : light-violet).

IR (ATR): 3379, 3368, 3074, 2901, 2888, 2845, 2215, 1603, 1573, 1513, 1463, 1449, 1322, 1285, 1164, 1129, 1064, 1026, 810, 799, 740, 503 $\mathrm{cm}^{-1}$.

${ }^{1} \mathrm{H}$ NMR $\left(300 \mathrm{MHz}, \mathrm{CDCl}_{3}\right): \delta=7.42-7.27(\mathrm{~m}, 2 \mathrm{H}, \mathrm{ArH}), 6.71-6.49(\mathrm{~m}$, $2 \mathrm{H}, \mathrm{ArH}), 5.02-4.79(\mathrm{~m}, 1 \mathrm{H}, \mathrm{NH}), 3.69-3.54(\mathrm{~m}, 1 \mathrm{H}, \mathrm{CH}), 2.09-1.55$ (m, $14 \mathrm{H}, \mathrm{CH}, \mathrm{CH}_{2}$ ).

${ }^{13} \mathrm{C}$ NMR $\left(75.53 \mathrm{MHz}, \mathrm{CDCl}_{3}\right): \delta=149.5\left(\mathrm{C}_{\mathrm{q}}\right), 134.2,132.9,118.2\left(\mathrm{C}_{\mathrm{q}}\right)$, 116.0, 111.2, $95.8\left(\mathrm{C}_{\mathrm{q}}\right), 56.5,37.6,37.3,31.6,31.5,27.4,27.2$.

HR-MS (GC-EI): $m / z[M]^{+}$calcd for $\mathrm{C}_{17} \mathrm{H}_{20} \mathrm{~N}_{2}$ : 252.1626; found: 252.1627.

\section{Methyl 2-(Adamantan-2-ylamino)benzoate (25)}

Prepared according to general procedure B from methyl anthranilate (39.2 $\mu \mathrm{L}, 300 \mu \mathrm{mol})$ and 2-adamantanone (50.1 mg, $330 \mu \mathrm{mol}) ; 24$ min reaction time; purified by column chromatography (cyclohexane-EtOAc, $150: 1,120: 1$, size: $4 \times 2.2 \mathrm{~cm})$; yield: $80.8 \mathrm{mg}(283 \mu \mathrm{mol}$, $94 \%$ ); light-yellow, waxy solid; $\mathrm{mp} 98-100{ }^{\circ} \mathrm{C} ; R_{f}=0.73$ (cyclohexaneEtOAc, 9:1) (254 nm, $366 \mathrm{~nm}$, CAM: crimson).

IR (ATR): 3360, 2961, 2905, 2853, 1681, 1604, 1579, 1516, 1456, 1433 , 1328, 1254, 1227, 1162, 1076, 1062, 796, 746, 701, 583, 551, 526, 497 $\mathrm{cm}^{-1}$. 
${ }^{1} \mathrm{H} \mathrm{NMR}\left(300 \mathrm{MHz}, \mathrm{CDCl}_{3}\right): \delta=8.21(\mathrm{br} \mathrm{s}, 1 \mathrm{H}, \mathrm{NH}), 7.83\left(\mathrm{~d},{ }^{3} \mathrm{HHH}_{\mathrm{HH}}=8.0\right.$ $\mathrm{Hz}, 1 \mathrm{H}, \mathrm{ArH}), 7.23\left(\mathrm{t},{ }^{3} \mathrm{HH}_{\mathrm{HH}}=7.8 \mathrm{~Hz}, 1 \mathrm{H}, \mathrm{ArH}\right), 6.59\left(\mathrm{~d},{ }^{3} \mathrm{JH}_{\mathrm{HH}}=8.6 \mathrm{~Hz}, 1\right.$ $\mathrm{H}, \mathrm{ArH}), 6.44\left(\mathrm{t}, 3_{\mathrm{HH}}=7.5 \mathrm{~Hz}, 1 \mathrm{H}, \mathrm{ArH}\right), 3.79\left(\mathrm{~s}, 3 \mathrm{H}, \mathrm{CH}_{3}\right), 3.66-3.52$ $(\mathrm{m}, 1 \mathrm{H}, \mathrm{CH}), 2.06-1.45\left(\mathrm{~m}, 14 \mathrm{H}, \mathrm{CH}_{2}, \mathrm{CH}\right)$.

${ }^{13} \mathrm{C} \operatorname{NMR}\left(75.53 \mathrm{MHz}, \mathrm{CDCl}_{3}\right): \delta=168.3\left(\mathrm{C}_{\mathrm{q}}\right), 149.3\left(\mathrm{C}_{\mathrm{q}}\right), 133.5,130.9$, 112.8, 110.6, $108.5\left(\mathrm{C}_{\mathrm{q}}\right), 55.0,50.4,36.7,36.3,30.8,30.6,26.4,26.3$.

HR-MS (GC-EI): $m / z[M]^{+}$calcd for $\mathrm{C}_{18} \mathrm{H}_{23} \mathrm{NO}_{2}$ : 285.1729; found: 285.1740 .

\section{2-(Pentan-2-ylamino)benzonitrile (26)}

Prepared according to general procedure $A$ from 2-aminobenzonitrile ( $121 \mathrm{mg}, 1.00 \mathrm{mmol}$ ) and 2-pentanone (164 $\mu \mathrm{L}, 1.5 \mathrm{mmol})$; $39 \mathrm{~h}$ reaction time; purified by column chromatography (cyclohexane-EtOAc, 50:1, size: $11 \times 2.6 \mathrm{~cm}$ ); yield: $150 \mathrm{mg}$ ( $795 \mu \mathrm{mol}, 80 \%$ ); light-yellow, sticky solid; $R_{f}=0.31$ (cyclohexane-EtOAc, 30:1) $(254 \mathrm{~nm}, 366 \mathrm{~nm}$, CAM: yellow).

IR (ATR): 3407, 3363, 2960, 2931, 2872, 2210, 1604, 1575, 1512, 1461, $1380,1324,1289,1167,1042,744,568,495 \mathrm{~cm}^{-1}$.

$\left.{ }^{1} \mathrm{H} \mathrm{NMR} \mathrm{(300} \mathrm{MHz,} \mathrm{CDCl}_{3}\right): \delta=7.41-7.29(\mathrm{~m}, 2 \mathrm{H}, \mathrm{ArH}), 6.70-6.55(\mathrm{~m}$, $2 \mathrm{H}, \mathrm{ArH}), 4.34$ (br s, $1 \mathrm{H}, \mathrm{NH}), 3.64-3.47(\mathrm{~m}, 1 \mathrm{H}, \mathrm{CH}), 1.67-1.31(\mathrm{~m}, 4$ $\left.\mathrm{H}, 2 \times \mathrm{CH}_{2}\right), 1.22\left(\mathrm{~d}, 3_{\mathrm{HH}}=6.3 \mathrm{~Hz}, 3 \mathrm{H}, \mathrm{CH}_{3}\right), 0.94\left(\mathrm{t}, 3_{\mathrm{HH}}=7.1 \mathrm{~Hz}, 3 \mathrm{H}\right.$, $\mathrm{CH}_{3}$ ).

${ }^{13} \mathrm{C}$ NMR $\left(76 \mathrm{MHz}, \mathrm{CDCl}_{3}\right): \delta=149.9\left(\mathrm{C}_{\mathrm{q}}\right), 134.3,133.0,118.2\left(\mathrm{C}_{\mathrm{q}}\right)$, 116.0, 111.0, $95.7\left(\mathrm{C}_{\mathrm{q}}\right), 48.3,39.2,20.7,19.4,14.1$.

HR-MS (GC-EI): $m / z$ [M] $]^{+}$calcd for $\mathrm{C}_{12} \mathrm{H}_{16} \mathrm{~N}_{2}$ : 188.1313; found: 188.1315 .

\section{2-[(4-Methylpentan-2-yl)amino]benzonitrile (27)}

Prepared according to general procedure A from 2-aminobenzonitrile (121 mg, $1.00 \mathrm{mmol}$ ) and 4-methylpentan-2-one (191 $\mu \mathrm{L}, 1.5 \mathrm{mmol})$; $39 \mathrm{~h}$ reaction time; purified by column chromatography (cyclohexane-EtOAc, 50:1, size: $11 \times 2.6 \mathrm{~cm})$; yield: $139 \mathrm{mg}$ (685 $\mu \mathrm{mol}, 69 \%)$; colorless, amorphous solid; $\mathrm{mp} 30-32{ }^{\circ} \mathrm{C} ; \mathrm{Rf}=0.34$ (cyclohexane-EtOAc, 30:1) (254 nm, 366 nm, CAM: yellow).

IR (ATR): 3356, 2959, 2918, 2863, 2839, 2214, 1604, 1574, 1516, 1464 , $1432,1366,1324,1292,1268,1165,1035,742,567,523,489,430$ $\mathrm{cm}^{-1}$.

${ }^{1} \mathrm{H}$ NMR $\left(300 \mathrm{MHz}, \mathrm{CDCl}_{3}\right): \delta=7.43-7.28(\mathrm{~m}, 2 \mathrm{H}, \mathrm{ArH}), 6.72-6.54(2$ $\mathrm{H}, \mathrm{ArH}), 4.30$ (br s, $1 \mathrm{H}, \mathrm{NH}), 3.70-3.50$ ( $\mathrm{m}, 1 \mathrm{H}, \mathrm{CH}-\mathrm{N}), 1.84-1.66$ (m, 1 $\mathrm{H}, \mathrm{CH}), 1.58-1.41\left(\mathrm{~m}, 1 \mathrm{H}, \mathrm{CH}_{2}\right), 1.40-1.27\left(\mathrm{~m}, 1 \mathrm{H}, \mathrm{CH}_{2}\right), 1.19\left(\mathrm{~d},{ }^{3} J_{\mathrm{HH}}=\right.$ $\left.6.9 \mathrm{~Hz}, 3 \mathrm{H}, \mathrm{CH}_{3}\right), 1.02-0.80\left(\mathrm{~m}, 6 \mathrm{H}, 2 \times \mathrm{CH}_{3}\right)$.

${ }^{13} \mathrm{C}$ NMR $\left(75.53 \mathrm{MHz}, \mathrm{CDCl}_{3}\right): \delta=149.9\left(\mathrm{C}_{\mathrm{q}}\right), 134.3,133.3,118.2\left(\mathrm{C}_{\mathrm{q}}\right)$, 116.0, 110.9, $95.7\left(\mathrm{C}_{\mathrm{q}}\right), 46.6,46.5,25.1,22.8,22.7,21.0$.

HR-MS (GC-EI): $m / z$ [M] ${ }^{+}$calcd for $\mathrm{C}_{13} \mathrm{H}_{18} \mathrm{~N}_{2}: 202.1470$; found: 202.1484 .

\section{Methyl 2-[(4-Methylpentan-2-yl)amino]benzoate (28)}

Prepared according to general procedure B from methyl anthranilate $(39.2 \mu \mathrm{L}, 300 \mu \mathrm{mol})$ and 4-methylpentan-2-one $(42.2 \mu \mathrm{L}, 330 \mu \mathrm{mol})$; left stirring in the thawing ice bath; $23 \mathrm{~h}$ reaction time; purified by column chromatography (cyclohexane-EtOAc, 150:1, 120:1, size: 12 $\times 2.4 \mathrm{~cm}$ ); yield: $30.6 \mathrm{mg}(130 \mu \mathrm{mol}, 43 \%)$; light-yellow, viscous liquid; $R_{f}=0.77$ (cyclohexane-EtOAc, 9:1) $(254 \mathrm{~nm}, 366 \mathrm{~nm}$, CAM: yellow).

IR (ATR): 3346, 2955, 2927, 2870, 1682, 1606, 1579, 1516, 1458, 1435 , $1325,1249,1224,1189,1163,1132,1083,1047,746,703,527 \mathrm{~cm}^{-1}$.
${ }^{1} \mathrm{H} \mathrm{NMR}\left(300 \mathrm{MHz}, \mathrm{CDCl}_{3}\right): \delta=7.89\left(\mathrm{~d},{ }^{3} J_{\mathrm{HH}}=8.0 \mathrm{~Hz}, 1 \mathrm{H}, \mathrm{ArH}\right), 7.66(\mathrm{br}$ s, $1 \mathrm{H}, \mathrm{NH}), 7.33\left(\mathrm{t},{ }^{3} J_{\mathrm{HH}}=7.8 \mathrm{~Hz}, 1 \mathrm{H}, \mathrm{ArH}\right), 6.70\left(\mathrm{~d},{ }^{3} J_{\mathrm{HH}}=8.5 \mathrm{~Hz}, 1 \mathrm{H}\right.$, $\operatorname{ArH}), 6.53\left(\mathrm{t},{ }^{3} J_{\mathrm{HH}}=7.5 \mathrm{~Hz}, 1 \mathrm{H}, \mathrm{ArH}\right), 3.85\left(\mathrm{~s}, 3 \mathrm{H}, \mathrm{CH}_{3}\right), 3.71-3.55(\mathrm{~m}$, $1 \mathrm{H}, \mathrm{CH}-\mathrm{N}), 1.87-1.70(\mathrm{~m}, 1 \mathrm{H}, \mathrm{CH}), 1.65-1.50\left(\mathrm{~m}, 1 \mathrm{H}, \mathrm{CH}_{2}\right), 1.44-1.15$ ( $\left.\mathrm{m}, 4 \mathrm{H}, \mathrm{CH}_{3}, \mathrm{CH}_{2}\right), 1.03-0.80\left(\mathrm{~m}, 6 \mathrm{H}, 2 \times \mathrm{CH}_{3}\right)$.

${ }^{13} \mathrm{C}$ NMR (75.53 MHz, $\left.\mathrm{CDCl}_{3}\right): \delta=169.3\left(\mathrm{C}_{\mathrm{q}}\right), 150.8\left(\mathrm{C}_{\mathrm{q}}\right), 134.7,132.0$, 114.0, 111.6, $109.7\left(\mathrm{C}_{\mathrm{q}}\right), 51.5,46.7,45.8,25.2,22.9,21.1$.

HR-MS (GC-EI): $m / z[M]^{+}$calcd for $\mathrm{C}_{14} \mathrm{H}_{21} \mathrm{NO}_{2}$ : 235.1572; found: 235.1585

\section{Methyl 2-[(4-Methoxy-4-oxobutan-2-yl)amino]benzoate (29)}

Prepared according to general procedure B from methyl anthranilate $(39.2 \mu \mathrm{L}, 300 \mu \mathrm{mol})$ and methyl acetoacetate $(36.0 \mu \mathrm{L}, 330 \mu \mathrm{mol}) ; 6 \mathrm{~h}$ reaction time; purified by column chromatography (cyclohexaneEtOAc, $17: 1$, size: $8 \times 0.8 \mathrm{~cm})$; yield: $50.8 \mathrm{mg}(202 \mu \mathrm{mol}, 67 \%)$; colorless, viscous liquid; $R_{f}=0.55$ (cyclohexane-EtOAc, 3:1) $(254 \mathrm{~nm}, 366$ $\mathrm{nm}, \mathrm{CAM}$ : orange-green).

IR (ATR): 3341, 2952, 1735, 1682, 1605, 1581, 1516, 1457, 1435, 1323 , 1299, 1239, 1190, 1162, 1130, 1077, 1047, 1005, 748, 703, $527 \mathrm{~cm}^{-1}$.

${ }^{1} \mathrm{H}$ NMR $\left(300 \mathrm{MHz}, \mathrm{CDCl}_{3}\right): \delta=8.00-7.65(\mathrm{~m}, 2 \mathrm{H}, \mathrm{NH}, \mathrm{ArH}), 7.41-7.30$ $(\mathrm{m}, 1 \mathrm{H}, \mathrm{ArH}), 6.75\left(\mathrm{~d},{ }^{3} J_{\mathrm{HH}}=8.5 \mathrm{~Hz}, 1 \mathrm{H}, \mathrm{ArH}\right), 6.59\left(\mathrm{t},{ }^{3} J_{\mathrm{HH}}=7.3 \mathrm{~Hz}, 1\right.$ $\mathrm{H}, \mathrm{ArH}), 4.16-3.99$ (m, $1 \mathrm{H} . \mathrm{CH}), 3.85\left(\mathrm{~s}, 3 \mathrm{H}, \mathrm{CH}_{3}\right), 3.69\left(\mathrm{~s}, 3 \mathrm{H}, \mathrm{CH}_{3}\right)$, $2.73\left(\mathrm{dd},{ }^{2} J_{\mathrm{HH}}=15.1 \mathrm{~Hz},{ }^{3} J_{\mathrm{HH}}=5.0 \mathrm{~Hz}, 1 \mathrm{H}, \mathrm{CH}_{2}\right), 2.43\left(\mathrm{dd},{ }^{2} J_{\mathrm{HH}}=15.1\right.$ $\left.\mathrm{Hz},{ }^{3} J_{\mathrm{HH}}=7.8 \mathrm{~Hz}, 1 \mathrm{H}, \mathrm{CH}_{2}\right), 1.33\left(\mathrm{~d},{ }^{3} J_{\mathrm{HH}}=6.4 \mathrm{~Hz}, 3 \mathrm{H}, \mathrm{CH}_{3}\right)$.

${ }^{13} \mathrm{C}$ NMR $\left(75.53 \mathrm{MHz}, \mathrm{CDCl}_{3}\right): \delta=172.1\left(\mathrm{C}_{\mathrm{q}}, \mathrm{C}-12\right), 169.1\left(\mathrm{C}_{\mathrm{q}}, \mathrm{C}-2\right)$, $149.8\left(\mathrm{C}_{\mathrm{q}}, \mathrm{C}-8\right), 134.8\left(\mathrm{CH}_{\text {arom }}\right), 132.0\left(\mathrm{CH}_{\text {arom }}\right), 115.0\left(\mathrm{CH}_{\text {arom }}\right), 111.8$ $\left(\mathrm{CH}_{\text {arom }}\right), 110.4\left(\mathrm{C}_{\mathrm{q}}, \mathrm{C}-3\right), 51.8\left(\mathrm{CH}_{3}\right), 51.6\left(\mathrm{CH}_{3}\right), 45.1(\mathrm{C}-10), 41.2(\mathrm{C}-$ 11), 20.8 (C-9).

HR-MS: $m / z$ [M] $]^{+}$calcd for $\mathrm{C}_{13} \mathrm{H}_{17} \mathrm{NO}_{4}$ : 251.1158; found: 251.1172 .

\section{Methyl 2-[(3,3-Dimethylbutan-2-yl)amino]benzoate (30)}

Prepared according to general procedure $\mathrm{B}$ from methyl anthranilate (39.2 $\mu \mathrm{L}, 300 \mu \mathrm{mol})$, pinacolone $(57.4 \mu \mathrm{L}, 450 \mu \mathrm{mol})$ and TMSOTf (139 $\mu \mathrm{L}, 750 \mu \mathrm{mol}$, instead of TMSCl); left stirring in the thawing ice bath; $20 \mathrm{~h}$ reaction time; purified by column chromatography (cyclohexane-EtOAc, 1:0, 120:1, size: $14 \times 2.5 \mathrm{~cm})$; yield: $35.2 \mathrm{mg}(150 \mu \mathrm{mol}$, $50 \%$ ); yellow, viscous liquid; $R_{f}=0.23$ (cyclohexane-EtOAc, 120:1) (254 nm, $366 \mathrm{~nm}$, CAM: orange-yellow).

IR (ATR): 3345, 2955, 2871, 1680, 1606, 1580, 1518, 1457, 1435, 1370 , $1350,1321,1254,1232,1189,1161,1119,1080,1046,745,702,520$ $\mathrm{cm}^{-1}$.

${ }^{1} \mathrm{H}$ NMR (300 MHz, $\left.\mathrm{CDCl}_{3}\right): \delta=8.17-7.81(\mathrm{~m}, 2 \mathrm{H}, \mathrm{NH}, \mathrm{ArH}), 7.37-7.27$ $(\mathrm{m}, 1 \mathrm{H}, \mathrm{ArH}), 6.73\left(\mathrm{~d},{ }^{3} J_{\mathrm{HH}}=8.6 \mathrm{~Hz}, 1 \mathrm{H}, \mathrm{ArH}\right), 6.51\left(\mathrm{t},{ }^{3} J_{\mathrm{HH}}=7.4 \mathrm{~Hz}, 1\right.$ $\mathrm{H}, \mathrm{ArH}), 3.85\left(\mathrm{~s}, 3 \mathrm{H}, \mathrm{CH}_{3}\right), 3.45-3.30(\mathrm{~m}, 1 \mathrm{H}, \mathrm{CH}), 1.14\left(\mathrm{~d},{ }^{3} J_{\mathrm{HH}}=6.5\right.$ $\left.\mathrm{Hz}, 3 \mathrm{H}, \mathrm{CH}_{3}\right), 1.02\left(\mathrm{~s}, 9 \mathrm{H}, 3 \times \mathrm{CH}_{3}\right)$.

${ }^{13} \mathrm{C}$ NMR $\left(75.53 \mathrm{MHz}, \mathrm{CDCl}_{3}\right): \delta=169.5\left(\mathrm{C}_{\mathrm{q}}\right), 151.3\left(\mathrm{C}_{\mathrm{q}}\right), 134.7,132.0$, 113.8, 111.6, 109.5 $\left(\mathrm{C}_{\mathrm{q}}\right)$, 56.6, 51.6, $35.0\left(\mathrm{C}_{\mathrm{q}}\right), 26.7,15.7$.

HR-MS: $m / z$ [M] $]^{+}$calcd for $\mathrm{C}_{14} \mathrm{H}_{21} \mathrm{NO}_{2}$ : 235.1572; found: 235.1602 .

\section{2-[(1-Phenylethyl)amino]benzonitrile (31)}

Prepared according to general procedure A from 2-aminobenzonitrile (121 mg, $1.00 \mathrm{mmol}$ ) and acetophenone $(178 \mu \mathrm{L}, 1.5 \mathrm{mmol}) ; 39 \mathrm{~h}$ reaction time; purified by column chromatography (cyclohexane-EtOAc, 50:1, size: $11 \times 2.6 \mathrm{~cm}$ ); yield: $156 \mathrm{mg}(701 \mu \mathrm{mol}, 70 \%)$; colorless, crystalline solid; $\mathrm{mp} 84^{\circ} \mathrm{C} ; R_{f}=0.27$ (cyclohexane-EtOAc, 30:1) (254 $\mathrm{nm}, 366 \mathrm{~nm}$, CAM: red-grey). 
IR (ATR): 3361, 3024, 2973, 2930, 2866, 2213, 1603, 1577, 1517, 1491 , $1470,1448,1342,1330,1316,1291,1261,1167,1147,1095,1023$, $947,759,741,700,608,565,541,484,445 \mathrm{~cm}^{-1}$.

${ }^{1} \mathrm{H}$ NMR $\left(300 \mathrm{MHz}, \mathrm{CDCl}_{3}\right): \delta=7.41-7.14(\mathrm{~m}, 7 \mathrm{H}, \mathrm{ArH}), 6.60\left(\mathrm{t},{ }^{3} J_{\mathrm{HH}}=\right.$ $7.5 \mathrm{~Hz}, 1 \mathrm{H}, \mathrm{ArH}), 6.41\left(\mathrm{~d},{ }^{3} J_{\mathrm{HH}}=8.5 \mathrm{~Hz}, 1 \mathrm{H}, \mathrm{ArH}\right), 4.89(\mathrm{br} \mathrm{s}, 1 \mathrm{H}, \mathrm{NH})$, 4.62-4.47 (m, $1 \mathrm{H}, \mathrm{CH}), 1.57\left(\mathrm{~d},{ }^{3} \mathrm{~J}_{\mathrm{HH}}=6.7 \mathrm{~Hz}, 1 \mathrm{H}, \mathrm{CH}_{3}\right)$.

${ }^{13} \mathrm{C}$ NMR $\left(75.53 \mathrm{MHz}, \mathrm{CDCl}_{3}\right): \delta=149.4\left(\mathrm{C}_{\mathrm{q}}\right), 143.8\left(\mathrm{C}_{\mathrm{q}}\right), 134.2,132.7$, 129.0, 127.4, 125.7, 118.1 $\left(\mathrm{C}_{\mathrm{q}}\right), 116.8,112.1,96.0\left(\mathrm{C}_{\mathrm{q}}\right), 53.4,25.0$

HR-MS (GC-EI): $m / z$ [M] $]^{+}$calcd for $\mathrm{C}_{15} \mathrm{H}_{14} \mathrm{~N}_{2}$ : 222.1157; found: 222.1167.

\section{Methyl 2-[(1-Phenylethyl)amino]benzoate (32)}

Prepared according to general procedure B from methyl anthranilate $(39.2 \mu \mathrm{L}, 300 \mu \mathrm{mol})$, acetophenone $(53.5 \mu \mathrm{L}, 450 \mu \mathrm{mol})$ and TMSOTf (139 $\mu \mathrm{L}, 750 \mu \mathrm{mol}$, instead of TMSCl); left stirring in the thawing ice bath; 23 h reaction time; purified by column chromatography (cyclohexane-EtOAc, 80:1, size: $8 \times 0.8 \mathrm{~cm})$; yield: $66.3 \mathrm{mg}(260 \mu \mathrm{mol}$, $87 \%$ ); colorless, viscous liquid; $R_{f}=0.14$ (cyclohexane-EtOAc, 120:1) (254 nm, 366 nm, CAM: orange-red).

IR (ATR): 3352, 3026, 2965, 2950, 2869, 1681, 1605, 1580, 1514, 1451, 1436, 1324, 1241, 1202, 1163, 1124, 1080, 1046, 1017, 747, 698, 557, $522 \mathrm{~cm}^{-1}$.

${ }^{1} \mathrm{H} \mathrm{NMR}\left(300 \mathrm{MHz}, \mathrm{CDCl}_{3}\right): \delta=8.13(\mathrm{br} \mathrm{s}, 1 \mathrm{H}, \mathrm{NH}), 7.82\left(\mathrm{dd},{ }^{3} J_{\mathrm{HH}}=8.0\right.$ $\left.\mathrm{Hz},{ }^{4} J_{\mathrm{HH}}=1.2 \mathrm{~Hz}, 1 \mathrm{H}, \mathrm{ArH}\right), 7.33-7.03(\mathrm{~m}, 6 \mathrm{H}, \mathrm{ArH}), 6.45\left(\mathrm{t},{ }^{3} J_{\mathrm{HH}}=7.6\right.$ $\mathrm{Hz}, 1 \mathrm{H}, \mathrm{ArH}), 6.36\left(\mathrm{~d},{ }^{3} J_{\mathrm{HH}}=8.5 \mathrm{~Hz}, 1 \mathrm{H}, \mathrm{ArH}\right), 4.57-4.41(\mathrm{~m}, 1 \mathrm{H}, \mathrm{CH})$, $3.81\left(\mathrm{~s}, 3 \mathrm{H}, \mathrm{O}-\mathrm{CH}_{3}\right), 1.51\left(\mathrm{~d},{ }^{3} \mathrm{~J}_{\mathrm{HH}}=6.7 \mathrm{~Hz}, 3 \mathrm{H}, \mathrm{CH}_{3}\right)$.

${ }^{13} \mathrm{C}$ NMR $\left(75.53 \mathrm{MHz}, \mathrm{CDCl}_{3}\right): \delta=169.4\left(\mathrm{C}_{\mathrm{q}}\right), 150.3\left(\mathrm{C}_{\mathrm{q}}\right), 145.0\left(\mathrm{C}_{\mathrm{q}}\right)$, 134.6, 131.6, 128.8, 127.0, 125.9, 114.9, 112.9, $110.2\left(\mathrm{C}_{\mathrm{q}}\right)$, 53.0, 51.6, 25.2 .

HR-MS (GC-EI): $m / z$ [M] $]^{+}$calcd for $\mathrm{C}_{16} \mathrm{H}_{17} \mathrm{NO}_{2}$ : 255.1259; found: 255.1267.

\section{Methyl 5-Bromo-2-\{[3-(methoxycarbonyl)cyclohexyl]amino\}ben- zoate (33)}

A dry $100 \mathrm{~mL}$ Schlenk flask with magnetic stirring bar was charged with methyl 2-amino-5-bromobenzoate hydrobromide $(2.37 \mathrm{~g}, 7.62$ mmol, 1.0 equiv) and the solid was dried under an oil-pump vacuum for $10 \mathrm{~min}$. To the Schlenk flask were added anhyd DMF (5 mL), methyl 3-oxocyclohexane-1-carboxylate ${ }^{40}$ (1.25 g, $8.00 \mathrm{mmol}, 1.05$ equiv), and TMSCl (2.95 mL, $22.9 \mathrm{mmol}, 3.0$ equiv) at r.t. The glass stopper was replaced by a rubber septum, the yellow two-phase mixture was cooled to $0{ }^{\circ} \mathrm{C}$, and $\mathrm{BH}_{3} \cdot \mathrm{THF}$ ( $7.60 \mathrm{~mL}, 7.60 \mathrm{~mol}, 1.0$ equiv) was added by syringe over a period of $42 \mathrm{~min}$. The flask with the colorless solution with colorless precipitate was sealed and was left stirring for 48 min at $0{ }^{\circ} \mathrm{C}$, when full conversion was detected by TLC. $\mathrm{H}_{2} \mathrm{O}(10 \mathrm{~mL})$ was added carefully, followed by neutralization with $25 \% \mathrm{NH}_{4} \mathrm{OH}$. The solvents were removed under vacuum and the residue was adsorbed on Celite ( $7 \mathrm{~g}$, suspending in $\mathrm{MeOH}$ ) and purified by column chromatography (cyclohexane-EtOAc, 20:1, 15:1, 12:1, 80 g silica gel, size: 18 $\times 3.5 \mathrm{~cm}$ ); yield: $2.70 \mathrm{~g}(7.30 \mu \mathrm{mol}, 96 \%)$; light-yellow, very viscous liquid.

HR-MS (DI-EI): $m / z$ [M] $]^{+}$calcd for $\mathrm{C}_{16} \mathrm{H}_{20} \mathrm{BrNO}_{4}$ : 369.0576; found: 369.0580 .

\section{$\left(1 S^{*}, 3 R^{*}\right)-33$}

$R_{f}=0.40$ (cyclohexane-EtOAc, 5:1) (254 nm, $366 \mathrm{~nm}$, CAM: orange).

IR (ATR): 3339, 2946, 2859, 1733, 1685, 1598, 1574, 1502, 1435, 1407 , 1308, 1245, 1201, 1127, 1108, 1074, 1015, 966, 898, 807, 787, 706, $644,569,519 \mathrm{~cm}^{-1}$.
${ }^{1} \mathrm{H} \mathrm{NMR}\left(300 \mathrm{MHz}, \mathrm{CDCl}_{3}\right): \delta=7.99\left(\mathrm{~d},{ }^{4} J_{\mathrm{HH}}=2.3 \mathrm{~Hz}, 1 \mathrm{H}, \mathrm{ArH}\right), 7.71(\mathrm{~d}$, $\left.{ }^{3} J_{\mathrm{HH}}=7.2 \mathrm{~Hz}, 1 \mathrm{H}, \mathrm{NH}\right), 7.37\left(\mathrm{dd},{ }^{3} J_{\mathrm{HH}}=9.0 \mathrm{~Hz},{ }^{4} J_{\mathrm{HH}}=2.2 \mathrm{~Hz}, 1 \mathrm{H}, \mathrm{ArH}\right)$, $6.58\left(\mathrm{~d},{ }^{3} \mathrm{JHH}_{\mathrm{HH}}=9.1 \mathrm{~Hz}, 1 \mathrm{H}, \mathrm{ArH}\right), 3.84\left(\mathrm{~s}, 3 \mathrm{H}, \mathrm{CH}_{3}\right), 3.66\left(\mathrm{~s}, 3 \mathrm{H}, \mathrm{CH}_{3}\right)$, 3.44-3.25 (m, $1 \mathrm{H}, \mathrm{CH}), 2.51-2.30\left(\mathrm{~m}, 2 \mathrm{H}, \mathrm{CH}, \mathrm{CH}_{2}\right), 2.19-1.84(\mathrm{~m}, 3$ $\left.\mathrm{H}, \mathrm{CH}_{2}\right), 1.52-1.12\left(\mathrm{~m}, 4 \mathrm{H}, \mathrm{CH}_{2}\right)$.

${ }^{13} \mathrm{C}$ NMR $\left(75.53 \mathrm{MHz}, \mathrm{CDCl}_{3}\right): \delta=175.3\left(\mathrm{C}_{\mathrm{q}}\right), 168.1\left(\mathrm{C}_{\mathrm{q}}\right), 149.1\left(\mathrm{C}_{\mathrm{q}}\right)$, $137.2\left(\mathrm{CH}_{\text {arom }}\right), 134.2\left(\mathrm{CH}_{\text {arom }}\right), 113.6\left(\mathrm{CH}_{\text {arom }}\right), 111.4\left(\mathrm{C}_{\mathrm{q}}\right), 105.6\left(\mathrm{C}_{\mathrm{q}}\right)$, $51.84,51.81,50.7,42.5,35.3,32.6,28.5,24.4$.

$\left(1 S^{*}, 3 S^{*}\right)-33$

$R_{f}=0.47$ (cyclohexane-EtOAc, 5:1) (254 nm, $366 \mathrm{~nm}$, CAM: orange). IR (ATR): 3344, 2936, 2860, 1730, 1683, 1575, 1502, 1435, 1314, 1215 , 1188, 1113, 1079, 1042, 967, 883, 808, 788, 706 644, 564, $521 \mathrm{~cm}^{-1}$.

${ }^{1} \mathrm{H} \mathrm{NMR}\left(300 \mathrm{MHz}, \mathrm{CDCl}_{3}\right): \delta=7.99\left(\mathrm{~d},{ }^{4} \mathrm{JHH}_{\mathrm{HH}}=2.3 \mathrm{~Hz}, 1 \mathrm{H}, \mathrm{ArH}\right), 7.90(\mathrm{~d}$, $\left.{ }^{3} J_{\mathrm{HH}}=6.8 \mathrm{~Hz}, 1 \mathrm{H}, \mathrm{NH}\right), 7.39\left(\mathrm{dd},{ }^{4} J_{\mathrm{HH}}=9.0,{ }^{3} J_{\mathrm{HH}}=2.2 \mathrm{~Hz}, 1 \mathrm{H}, \mathrm{ArH}\right), 6.67$ (d, $\left.{ }^{3} J_{\mathrm{HH}}=9.1 \mathrm{~Hz}, 1 \mathrm{H}, \mathrm{ArH}\right), 3.92-3.62\left(\mathrm{~m}, 7 \mathrm{H}, \mathrm{CH}, 2 \times \mathrm{CH}_{3}\right), 2.77-2.63$ (m, $1 \mathrm{H}, \mathrm{CH}), 2.14-1.96\left(\mathrm{~m}, 1 \mathrm{H}, \mathrm{CH}_{2}\right), 1.89-1.49\left(\mathrm{~m}, 7 \mathrm{H}, \mathrm{CH}_{2}\right)$.

${ }^{13} \mathrm{C}$ NMR $\left(75.53 \mathrm{MHz}, \mathrm{CDCl}_{3}\right): \delta=175.9\left(\mathrm{C}_{\mathrm{q}}\right), 168.3\left(\mathrm{C}_{\mathrm{q}}\right), 149.2\left(\mathrm{C}_{\mathrm{q}}\right)$, $137.4\left(\mathrm{CH}_{\text {arom }}\right), 134.1\left(\mathrm{CH}_{\text {arom }}\right), 113.7\left(\mathrm{CH}_{\text {arom }}\right), 111.3\left(\mathrm{C}_{\mathrm{q}}\right), 105.6\left(\mathrm{C}_{\mathrm{q}}\right)$, 51.8, 47.0, 38.7, 32.6, 31.1, 28.1, 21.2.

\section{Methyl 5-Iodo-2-\{[3-(methoxycarbonyl)cyclohexyl]amino\}benzo- ate (34)}

A dry $100 \mathrm{~mL}$ Schlenk flask with magnetic stirring bar was charged with methyl 2-amino-5-iodobenzoate hydrochloride (6.69 g, 21.3 mmol, 1.0 equiv) and the solid was dried under an oil-pump vacuum for $10 \mathrm{~min}$. To the Schlenk flask were added anhyd DMF ( $40 \mathrm{~mL})$ followed by methyl 3-oxocyclohexane-1-carboxylate ${ }^{40}$ (3.50 g, 22.4 mmol, 1.05 equiv) and TMSCl ( $8.30 \mathrm{~mL}, 64.0 \mathrm{mmol}, 3.0$ equiv). The glass stopper was replaced by a rubber septum, the flesh-colored, two-phase mixture was cooled with an ice bath, and $\mathrm{BH}_{3} \cdot \mathrm{THF}(23.0$ $\mathrm{mL}, 23.0 \mathrm{mmol}, 1.08$ equiv) was added over a period of $60 \mathrm{~min}$. The flask was sealed and the mixture was left stirring at $0{ }^{\circ} \mathrm{C}$ until full conversion of the starting material was detected by TLC ( $30 \mathrm{~min})$. The light-yellow solution was carefully treated with $\mathrm{H}_{2} \mathrm{O}(20 \mathrm{~mL})$, followed by neutralization with $25 \% \mathrm{NH}_{4} \mathrm{OH}$. The solvents were removed under vacuum and the residue was adsorbed on Celite (24 g, suspended in $\mathrm{MeOH}$ ) and purified by column chromatography (cyclohexaneEtOAc, 15:1, 10:1, 8:1, 6:1, 300 g silica gel, size: $13 \times 7.5 \mathrm{~cm}$ ); yield: $8.61 \mathrm{~g}$ (20.6 mmol, 97\%); yellow, very viscous liquid.

HR-MS (DI-EI): $m / z[M]^{+}$calcd for $\mathrm{C}_{16} \mathrm{H}_{20} \mathrm{INO}_{4}$ : 417.0437; found: 417.0443.

\section{$\left(1 S^{*}, 3 R^{*}\right)-34$}

$R_{f}=0.46$ (cyclohexane-EtOAc, 4:1) (254 nm, $366 \mathrm{~nm}$, CAM: yellow). IR (ATR): 3338, 2937, 2859, 1732, 1682, 1591, 1571, 1500, 1435, 1403 , 1320, 1308, 1247, 1201, 1127, 1106, 1075, 1015, 965, 899, 806, 788, $758,697,637,572,518 \mathrm{~cm}^{-1}$.

${ }^{1} \mathrm{H}$ NMR $\left(300 \mathrm{MHz}, \mathrm{CDCl}_{3}\right): \delta=8.15\left(\mathrm{~d},{ }^{4} J_{\mathrm{HH}}=2.1 \mathrm{~Hz}, 1 \mathrm{H}, \mathrm{ArH}\right), 7.73(\mathrm{~d}$, $\left.{ }^{3} J_{\mathrm{HH}}=7.2 \mathrm{~Hz}, 1 \mathrm{H}, \mathrm{NH}\right), 7.51\left(\mathrm{dd},{ }^{3} J_{\mathrm{HH}}=8.9 \mathrm{~Hz},{ }^{4} J_{\mathrm{HH}}=1.9 \mathrm{~Hz}, 1 \mathrm{H}, \mathrm{ArH}\right)$, $6.48\left(\mathrm{~d},{ }^{3} \mathrm{~J}_{\mathrm{HH}}=9.0 \mathrm{~Hz}, 1 \mathrm{H}, \mathrm{ArH}\right), 3.83\left(\mathrm{~s}, 3 \mathrm{H}, \mathrm{CH}_{3}\right), 3.66\left(\mathrm{~s}, 3 \mathrm{H}, \mathrm{CH}_{3}\right)$, 3.41-3.25 (m, $1 \mathrm{H}, \mathrm{CH}), 2.52-2.28\left(\mathrm{~m}, 2 \mathrm{H}, \mathrm{CH}, \mathrm{CH}_{2}\right), 2.17-1.82(\mathrm{~m}, 3$ $\left.\mathrm{H}, \mathrm{CH}_{2}\right), 1.52-1.11\left(\mathrm{~m}, 4 \mathrm{H}, \mathrm{CH}_{2}\right)$.

${ }^{13} \mathrm{C}$ NMR $\left(75.53 \mathrm{MHz}, \mathrm{CDCl}_{3}\right): \delta=175.3\left(\mathrm{C}_{\mathrm{q}}\right), 168.0\left(\mathrm{C}_{\mathrm{q}}\right), 149.5\left(\mathrm{C}_{\mathrm{q}}\right)$, $142.7\left(\mathrm{CH}_{\text {arom }}\right), 140.2\left(\mathrm{CH}_{\text {arom }}\right), 114.1\left(\mathrm{CH}_{\text {arom }}\right), 112.2\left(\mathrm{C}_{\mathrm{q}}\right), 73.9\left(\mathrm{C}_{\mathrm{q}}\right)$, $51.84,51.79,50.6,42.4,35.3,32.6,28.4,24.4$.

\section{$\left(1 S^{*}, 3 S^{*}\right)-34$}

$R_{f}=0.51$ (cyclohexane-EtOAc, 4:1) (254 nm, $366 \mathrm{~nm}$, CAM: yellow). 
IR (ATR): 3342, 2946, 2859, 1730, 1681, 1591, 1571, 1499, 1435, 1404, $1314,1215,1188,1140,1111,1081,1042,807,788,697,644,562$, $520 \mathrm{~cm}^{-1}$.

${ }^{1} \mathrm{H} \mathrm{NMR}\left(300 \mathrm{MHz}, \mathrm{CDCl}_{3}\right): \delta=8.16\left(\mathrm{~d},{ }^{4} J_{\mathrm{HH}}=2.0 \mathrm{~Hz}, 1 \mathrm{H}, \mathrm{ArH}\right), 7.93(\mathrm{~d}$, $\left.{ }^{3} J_{\mathrm{HH}}=7.0 \mathrm{~Hz}, 1 \mathrm{H}, \mathrm{NH}\right), 7.53\left(\mathrm{dd},{ }^{3} J_{\mathrm{HH}}=8.9 \mathrm{~Hz},{ }^{4} J_{\mathrm{HH}}=1.6 \mathrm{~Hz}, 1 \mathrm{H}, \mathrm{ArH}\right)$, $6.57\left(\mathrm{~d},{ }^{3} J_{\mathrm{HH}}=9.0 \mathrm{~Hz}, 1 \mathrm{H}, \mathrm{ArH}\right), 3.94-3.62\left(\mathrm{~m}, 7 \mathrm{H}, 2 \times \mathrm{CH}_{3}, \mathrm{CH}\right), 2.78-$ $2.62(\mathrm{~m}, 1 \mathrm{H}, \mathrm{CH}), 2.13-1.92\left(\mathrm{~m}, 1 \mathrm{H}, \mathrm{CH}_{2}\right), 1.90-1.51\left(\mathrm{~m}, 7 \mathrm{H}, \mathrm{CH}_{2}\right)$.

${ }^{13} \mathrm{C}$ NMR $\left(75.53 \mathrm{MHz}, \mathrm{CDCl}_{3}\right): \delta=175.9\left(\mathrm{C}_{\mathrm{q}}\right), 168.2\left(\mathrm{C}_{\mathrm{q}}\right), 149.6\left(\mathrm{C}_{\mathrm{q}}\right)$, $142.8\left(\mathrm{CH}_{\text {arom }}\right), 140.1\left(\mathrm{CH}_{\text {arom }}\right), 114.3\left(\mathrm{CH}_{\text {arom }}\right), 112.1\left(\mathrm{C}_{\mathrm{q}}\right), 73.9\left(\mathrm{C}_{\mathrm{q}}\right)$, $51.8\left(2 \times \mathrm{CH}_{3}\right), 46.9,38.7,32.5,31.0,28.1,21.2$.

\section{Acknowledgment}

Financial support by the Austrian Science Fund FWF (Project I-668) and NAWI Graz is gratefully acknowledged. We thank Prof. Wulf Blankenfeldt (Helmholtz-Zentrum für Infektionsforschung, Braunschweig/D) for our continuous collaboration in the development of inhibitors of the phenazine biosynthesis pathway, Prof. Hansjörg Weber for NMR measurements, and Mario Mugitsch, Manuel Köckinger, and Minh-Hao Hoang for skillful assistance in the lab.

\section{Supporting Information}

Supporting information for this article is available online at http://dx.doi.org/10.1055/s-0035-1561384.

\section{References}

(1) Mentel, M.; Ahuja, E. G.; Mavrodi, D. V.; Breinbauer, R.; Thomashow, L. S.; Blankenfeldt, W. ChemBioChem 2009, 10, 2295.

(2) Ahuja, E. G.; Janning, P.; Mentel, M.; Graebsch, A.; Breinbauer, R.; Hiller, W.; Costisella, B.; Thomashow, L. S.; Mavrodi, D. V.; Blankenfeldt, W. J. Am. Chem. Soc. 2008, 130, 17053.

(3) Mentel, M.; Blankenfeldt, W.; Breinbauer, R. Angew. Chem. Int. Ed. 2009, 48, 9084.

(4) (a) Graebe, C.; Lagodzinski, K. Chem. Ber. 1892, 25, 1733. (b) Ullmann, F.; Bielecki, J. Chem. Ber. 1901, 34, 2174. (c) Ullmann, F. Chem. Ber. 1903, 36, 2382. (d) Goldberg, I. Chem. Ber. 1906, 39, 1691. (e) For a review, see: Ley, S. V.; Thomas, A. W. Angew. Chem. Int. Ed. 2003, 42, 5400.

(5) For borohydrides, see: (a) Abdel-Magid, A. F.; Maryanoff, C. A. Synlett 1990, 537. (b) Abdel-Magid, A. F.; Carson, K. G.; Harris, B. D.; Maryanoff, C. A.; Shah, R. D. J. Org. Chem. 1996, 61, 3849. (c) Cho, B. T.; Kang, S. K. Synlett 2004, 1484. (d) Miriyala, B.; Bhattacharyya, S.; Williamson, J. S. Tetrahedron 2004, 60, 1463. (e) Gutierrez, C. D.; Bavetsias, V.; McDonald, E. Tetrahedron Lett. 2005, 46, 3595. (f) McLaughlin, M.; Palucki, M.; Davies, I. W. Org. Lett. 2006, 8, 3307. (g) Abdel-Magid, A. F.; Mehrman, S. J. Org. Process Res. Dev. 2006, 10, 971. (h) Tajbakhsh, M.; Hosseinzadeh, R.; Alinezhad, H.; Ghahari, S.; Heydari, A.; Khaksar, S. Synthesis 2011, 490. (i) Bogolubsky, A. V.; Moroz, Y. S.; Pipko, S. E.; Panov, D. M.; Konovets, A. I.; Doroschuk, R.; Tolmachev, A. Synthesis 2014, 46, 1765.

(6) For reductive aminations with $\mathrm{Et}_{3} \mathrm{SiH}$, see: (a) Han, Y.; Chorev, M. J. Org. Chem. 1999, 64, 1972. (b) Lee, O.-Y.; Law, K.-L.; Ho, C.Y.; Yang, D. J. Org. Chem. 2008, 73, 8829. (c) Lee, O.-Y.; Law, K.-L.; Yang, D. Org. Lett. 2009, 11, 3302. (d) Prakash, G. K. S.; Do, C.; Mathew, T.; Olah, G. A. Catal. Lett. 2010, 137, 111. (e) Gellert, B.
A.; Kahlcke, N.; Feurer, M.; Roth, S. Chem. Eur.J. 2011, 17, 12203. (f) Matsumura, T.; Nakada, M. Tetrahedron Lett. 2014, 55, 1829. With PMHS, see: (g) Chandrasekhar, S.; Reddy, C. R.; Ahmed, M. Synlett 2000, 1655. (h) Patel, J. P.; Li, A.-H.; Dong, H.; Korlipara, V. L.; Mulvihill, M. J. Tetrahedron Lett. 2009, 50, 5975. (i) Kumar, V.; Sharma, S.; Sharma, U.; Singh, B.; Kumar, N. Green Chem. 2012, 14, 3410. (j) Nayal, O. S.; Bhatt, V.; Sharma, S.; Kumar, N. J. Org. Chem. 2015, 80, 5912. With $\mathrm{PhSiH}_{3}$, see: (k) Apodaca, R.; Xiao, W. Org. Lett. 2001, 3, 1745. (l) Smith, C. A.; Cross, L. E.; Hughes, K.; Davis, R. E.; Judd, D. B.; Merritt, A. T. Tetrahedron Lett. 2009, 50, 4906.

(7) For transfer hydrogenations, see: (a) Itoh, T.; Nagata, K.; Miyazaki, M.; Ishikawa, H.; Kurihara, A.; Ohsawa, A. Tetrahedron 2004, 60, 6649. (b) Menche, D.; Hassfeld, J.; Li, J.; Menche, G.; Ritter, A.; Rudolph, S. Org. Lett. 2006, 8, 741. (c) Huang, Y.-B.; Yi, W.-B.; Cai, C. J. Fluorine Chem. 2010, 131, 879. (d) Nguyen, Q. P. B.; Kim, T. H. Tetrahedron Lett. 2011, 52, 5004. (e) Zhu, C.; Akiyama, T. Synlett 2011, 1251. (f) Zhang, M.; Yang, H.; Zhang, Y.; Zhu, C.; Li, W.; Cheng, Y.; Hu, H. Chem. Commun. 2011, 47, 6605. (g) Lei, Q.; Wei, Y.; Talwar, D.; Wang, C.; Xue, D.; Xiao, J. Chem. Eur. J. 2013, 19, 4021. (h) Talwar, D.; Salguero, N. P.; Robertson, C. M.; Xiao, J. Chem. Eur. J. 2014, 20, 245. (i) Gülcemal, D.; Gülcemal, S.; Robertson, C. M.; Xiao, J. Organometallics 2015, 34, 4394.

(8) For metal-catalyzed reductive aminations, see: (a) Imao, D.; Fujihara, S.; Yamamoto, T.; Ohta, T.; Ito, Y. Tetrahedron 2005, 61, 6988. (b) Li, C.; Villa-Marcos, B.; Xiao, J. J. Am. Chem. Soc. 2009, 131, 6967. (c) Rubio-Pérez, L.; Pérez-Flores, F. J.; Sharma, P.; Velasco, L.; Cabrera, A. Org. Lett. 2009, 11, 265. (d) Steinhuebel, D.; Sun, Y.; Matsumura, K.; Sayo, N.; Saito, T. J. Am. Chem. Soc. 2009, 131, 11316. (e) Werkmeister, S.; Junge, K.; Beller, M. Green Chem. 2012, 14, 2371. (f) Pagnoux-Ozherelyeva, A.; Pannetier, N.; Mbaye, M. D.; Gaillard, S.; Renaud, J.-L. Angew. Chem. Int. Ed. 2012, 51, 4976. (g) Chusov, D.; List, B. Angew. Chem. Int. Ed. 2014, 53, 5199. (h) Kolesnikov, P. N.; Yagafarov, N. Z.; Usanov, D. L.; Maleev, V. I.; Chusov, D. Org. Lett. 2015, 17, 173. (i) Jumde, V. R.; Petricci, E.; Petrucci, C.; Santillo, N.; Taddei, M.; Vaccaro, L. Org. Lett. 2015, 17, 3990.

(9) For reductive amination with $\mathrm{BH}_{3} \cdot \mathrm{THF}$, see: (a) Heydari, A.; Tavakol, H.; Aslanzadeh, S.; Azarnia, J.; Ahmadi, N. Synthesis 2005, 627. (b) Chen, W.-C.; Hsu, Y.-C.; Lee, C.-Y.; Yap, G. P. A.; Ong, T.-G. Organometallics 2013, 32, 2435. (c) For $\mathrm{BH}_{3} \cdot \mathrm{SMe}_{2}$, see: Figge, A.; Altenbach, H. J.; Brauer, D. J.; Tielmann, P. Tetrahedron: Asymmetry 2002, 13, 137. (d) See also: Tokizane, M.; Sato, K.; Sakami, Y.; Imori, Y.; Matsuo, C.; Ohta, T.; Ito, Y. Synthesis 2010, 36. (e) For a review on amine-boranes, see: Kanth, J. V. B. Aldrichimica Acta 2002, 35, 57. (f) For pyr- $\mathrm{BH}_{3}$, see: Pelter, A.; Rosser, R. M. J. Chem. Soc., Perkin Trans. 1 1984, 717. (g) See also: Bomann, M. D.; Guch, I. C.; DiMare, M. J. Org. Chem. 1995, 60, 5995. (h) See also: Tapia, I.; Alonso-Cires, L.; López-Tudanca, P. L.; Mosquera, R.; Labeaga, L.; Innerárity, A.; Orjales, A. J. Med. Chem. 1999, 42, 2870. (i) For picoline-borane, see: Sato, S.; Sakamoto, T.; Miyazawa, E.; Kikugawa, Y. Tetrahedron 2004, 60, 7899. (j) See also: Kawase, Y.; Yamagishi, T.; Kutsuma, T.; Zhibao, H.; Yamamoto, Y.; Kimura, T.; Nakata, T.; Kataoka, T.; Yokomatsu, T. Org. Process Res. Dev. 2012, 16, 495. (k) For $\mathrm{NH}_{3} \cdot \mathrm{BH}_{3}$, see: Ramachandran, P. V.; Gagare, P. D.; Sakavuyi, K.; Clark, P. Tetrahedron Lett. 2010, 51, 3167. (1) For 5-ethyl-2methylpyridine-borane, see: Burkhardt, E. R.; Coleridge, B. M. Tetrahedron Lett. 2008, 49, 5152. (m) For 9-BBN, see: Qu, B.; Haddad, N.; Rodriguez, S.; Lee, H.; Ma, S.; Zeng, X.; Reeves, D. C.; Sidhu, K. P. S.; Lorenz, J. C.; Grinberg, N.; Busacca, C. A.; 
Krishnamurthy, D.; Senanayake, C. H. Tetrahedron Lett. 2012, 53, 1982. (n) For decaborane, see: Bae, J. W.; Lee, S. H.; Cho, Y. J.; Yoon, C. M. J. Chem. Soc., Perkin Trans. 1 2000, 145.

(10) Baxter, E. W.; Reitz, A. B. Reductive Aminations of Carbonyl Compounds with Borohydride and Borane Reducing Agents, In Organic Reactions; Vol. 59; John Wiley \& Sons: New York, 2002, $1-714$.

(11) Detzer, N.; Burkhard, O.; Schaffrin, H.; Liptay, W. Z. Naturforsch., B: J. Chem. Sci. 1987, 42, 1129.

(12) Kudzma, L. V.; Evans, S. M.; Turnbull, S. P. Jr.; Severnak, S. A.; Ezell, E. F. Bioorg. Med. Chem. Lett. 1995, 5, 1177.

(13) For reductive aminations of electron-deficient amines, see: (a) Ref. 6g. (b) Boros, E. E.; Thompson, J. B.; Katamreddy, S. R.; Carpenter, A. J. J. Org. Chem. 2009, 74, 3587. (c) Ghorai, P.; Das, B. G. Chem. Commun. 2012, 48, 8276. (d) Ghorai, P.; Das, B. G. Org. Biomol. Chem. 2013, 11, 4379.

(14) Nakanishi, M.; Katayev, D.; Besnard, C.; Kündig, E. P. Angew. Chem. Int. Ed. 2011, 50, 7438.

(15) Liu, Y.; Du, H. J. Am. Chem. Soc. 2013, 135, 6810.

(16) Mattson, R. J.; Pham, K. M.; Leuck, D. J.; Cowen, K. A. J. Org. Chem. 1990, 55, 2552.

(17) DiCesare, J. C.; White, C. E.; Rasmussen, W. E.; White, B. M.; McComas, C. B.; Craft, L. E. Synth. Commun. 2005, 35, 663.

(18) Menche, D.; Arikan, F.; Li, J.; Rudolph, S. Org. Lett. 2007, 9, 267.

(19) Wilk, W.; Nören-Müller, A.; Kaiser, M.; Waldmann, H. Chem. Eur. J. 2009, 15, 11976.

(20) Coe, J. W.; Vetelino, M. G.; Bradlee, M. J. Tetrahedron Lett. 1996, 37, 6045.

(21) Liu, Y.; Prashad, M.; Shieh, W.-C. Org. Process Res. Dev. 2014, 18, 239.

(22) Gribble, A. W.; Lord, P. D.; Skotnicki, J.; Dietz, S. E.; Eaton, J. T.; Johnson, J. L. J. Am. Chem. Soc. 1974, 96, 7812.

(23) Gribble, G. W.; Jasinski, J. M.; Pellicone, J. T.; Panetta, J. A. Synthesis 1978, 766.

(24) Marchini, P.; Liso, G.; Reho, A. J. Org. Chem. 1975, 40, 3453.

(25) (a) Giannis, A.; Sandhoff, K. Angew. Chem. Int. Ed. 1989, 28, 218. (b) Kanth, J. V. B.; Periasamy, M. J. Org. Chem. 1991, 56, 5964. (c) Prasad, A. S. B.; Kanth, J. V. B.; Periasamy, M. Tetrahedron 1992, 48, 4623. (d) Bolm, C.; Seger, A.; Felder, M. Tetrahedron Lett. 1993, 34, 8079. (e) Romero, A. G.; Leiby, J. A.; Mizsak, S. A. J. Org. Chem. 1996, 61, 6974. (f) Jiang, B.; Feng, Y.; Zheng, J. Tetrahedron Lett. 2000, 41, 10281. (g) For a review on the use of organosilicon compounds as water scavengers, see: Volochnyuk, D. M.; Ryabukhin, S. V.; Plaskon, A. S.; Grygorenko, O. O. Synthesis 2009, 22, 3719.
(26) (a) Xu, D.; Ciszewski, L.; Li, T.; Repič, O.; Blacklock, T. J. Tetrahedron Lett. 1998, 39, 1107. (b) Ciszewski, L.; Xu, D.; Repič, O.; Blacklock, T. J. Tetrahedron Lett. 2004, 45, 8091.

(27) Brown, H. C. U.S. Patent 3,634,277, 1972.

(28) (a) Brown, H. C.; Heim, P.; Yoon, N. M. J. Am. Chem. Soc. 1970, 92, 1637. (b) Lane, C. F. Chem. Rev. 1976, 76, 773. (c) Potyen, M.; Josyula, K. V. B.; Schuck, M.; Lu, S.; Gao, P.; Hewitt, C. Org. Process Res. Dev. 2007, 11, 210. For an industrial incident involving a $400 \mathrm{~L}$ cylinder of $2 \mathrm{M}$ borane-THF, see: (d) Reisch, M. Chem. Eng. News 2002, 80,26 7. (e) am Ende, D. J.; Vogt, P. F. Org. Process Res. Dev. 2003, 7, 1029.

(29) (a) Borch, R. F.; Bernstein, M. D.; Durst, H. D. J. Am. Chem. Soc. 1971, 93, 2897. (b) Schellenberg, K. A. J. Org. Chem. 1963, 28 , 3259.

(30) (a) Cragg, G. M. L. In Organoboranes in Organic Synthesis; Marcel Dekker: New York, 1973, 324. (b) Cha, J. S.; Moon, S. J.; Park, J. H. J. Org. Chem. 2001, 66, 7514.

(31) Chaikin, S. W.; Brown, W. G. J. Am. Chem. Soc. 1949, 71, 122.

(32) Seo, H.; Snead, D. R.; Abboud, K. A.; Hong, S. Organometallics 2011, 30, 5725.

(33) Hollmann, D.; Bähn, S.; Tillack, A.; Beller, M. Angew. Chem. Int. Ed. 2007, 46, 8291.

(34) Diethyl (2-aminophenyl)phosphonate was prepared from 2bromoaniline by using a procedure by: Gooßen, L. J.; Dezfuli, M. K. Synlett 2005, 445.

(35) Zeng, L.; Fu, H.; Qiao, R.; Jiang, Y.; Zhao, Y. Adv. Synth. Catal. 2009, 351, 1671.

(36) Bruncko, M.; Oost, T. K.; Belli, B. A.; Ding, H.; Joseph, M. K.; Kunzer, A.; Martineau, D.; McClellan, W. J.; Mitten, M.; Ng, S.-C.; Nimmer, P. M.; Oltersdorf, T.; Park, C.-M.; Petros, A. M.; Shoemaker, A. R.; Song, X.; Wang, X.; Wendt, M. D.; Zhang, H.; Fesik, S. W.; Rosenberg, S. H.; Elmore, S. W. J. Med. Chem. 2007, 50,641 .

(37) Sreedhar, B.; Arundhathi, R.; Reddy, P. L.; Reddy, M. A.; Kantam, M. L. Synthesis 2009, 2517.

(38) Shafir, A.; Buchwald, S. L. J. Am. Chem. Soc. 2006, 128, 8742.

(39) Likhar, P. R.; Arundhathi, R.; Kantam, M. L.; Prathima, P. S. Eur. J. Org. Chem. 2009, 5383.

(40) (a) Methyl 3-oxocyclohexane-1-carboxylate was prepared from 3-oxocyclohexane-1-carbonitrile by using a procedure by: Chow, S.; Fletcher, M. T.; Lambert, L. K.; Gallagher, O. P.; Moore, C. J.; Cribb, B. W.; Allsopp, P. G.; Kitching, W. J. Org. Chem. 2005, 70, 1808. (b) 3-Oxocyclohexane-1-carbonitrile was prepared from cyclohex-2-en-1-one by using a procedure by: Winkler, M.; Knall, A. C.; Kulterer, M. R.; Klempier, N. J. Org. Chem. 2007, $72,7423$. 